\title{
Process Analysis of Anaerobic Fermentation Exposure to Metal Mixtures
}

\author{
Yonglan Tian, Huayong Zhang * (D), Lei Zheng, Shusen Li, He Hao, Meixiao Yin, Yudong Cao \\ and Hai Huang
}

Research Center for Engineering Ecology and Nonlinear Science, North China Electric Power University, Beijing 102206, China

* Correspondence: rceens@ncepu.edu.cn; Tel.: +86-010-61773936

Received: 24 June 2019; Accepted: 8 July 2019; Published: 10 July 2019

\begin{abstract}
Anaerobic fermentation is a cost-effective biowaste disposal approach. During fermentation, microorganisms require a trace amount of metals for optimal growth and performance. This study investigated the effects of metal mixtures on biogas properties, process stability, substrate degradation, enzyme activity, and microbial communities during anaerobic fermentation. The addition of iron $(\mathrm{Fe})$, nickel $(\mathrm{Ni})$, and zinc $(\mathrm{Zn})$ into a copper $(\mathrm{Cu})$-stressed fermentation system resulted in higher cumulative biogas yields, ammonia nitrogen $\left(\mathrm{NH}_{4}{ }^{+}-\mathrm{N}\right)$ concentrations and coenzyme $\mathrm{F}_{420}$ activities. $\mathrm{Ni}$ and $\mathrm{Zn}$ addition enhanced process stability and acetate utilization. The addition of these metals also improved and brought forward the peak daily biogas yields as well as increased $\mathrm{CH}_{4}$ content to 88.94 and $86.58 \%$, respectively. Adding $\mathrm{Zn}$ into the $\mathrm{Cu}$-stressed system improved the abundance of Defluviitoga, Fibrobacter and Methanothermobacter, the degradation of cellulose, and the transformation of $\mathrm{CO}_{2}$ to $\mathrm{CH}_{4}$. The bacterial and archaeal communities were responsible for the degradation of lignocelluloses and $\mathrm{CH}_{4}$ production during the fermentation process. This study supports the reutilization of heavy metal-contaminated biowaste and provides references for further research on heavy metals impacted anaerobic fermentation.
\end{abstract}

Keywords: heavy metals; biogas production; substrate biodegradation; enzyme activity; microbial communities; methanogens

\section{Introduction}

The rapid increase in population, urbanization and industrialization has given rise to the excessive discharge of contaminants into the environment [1]. Unlike organic contaminants, heavy metals are toxic, not biodegradable and can be accumulated in living organisms [1]. Thus, reliable, environmentally-friendly technologies such as phytoremediation are required to treat wastewaters $[2,3]$. Phytoremediation involves the removal of pollutants by rapidly growing aquatic plants via plant uptake and metabolism. Unfortunately, phytoremediation produces a large amount of biomass which might be a potential source of secondary pollution $[4,5]$. Anaerobic fermentation is a relatively more efficient process for biomass waste reduction [4,5]. During anaerobic fermentation, microorganisms require trace amounts of different metals for their optimal growth and performance [6]. In general, heavy metals promote biogas production at certain concentrations [5,7-9] but inhibit anaerobic fermentation at higher concentrations $[8,10,11]$. However, the co-occurrence of different metals may induce complex reactions which may hinder the efficient utilization of biowaste.

Since $\mathrm{Cu}, \mathrm{Fe}, \mathrm{Ni}$ and $\mathrm{Zn}$ are widely distributed in terrestrial and aquatic systems, plants contaminated with those metals are often used in anaerobic fermentation [8,12-14]. The impacts of $\mathrm{Cu}$, $\mathrm{Fe}, \mathrm{Ni}$ and $\mathrm{Zn}$, separately, on anaerobic fermentation were studied in recent decades. Table 1 summaries the previous studies about the impact of $\mathrm{Cu}, \mathrm{Fe}, \mathrm{Ni}$ and $\mathrm{Zn}$ on biogas production. Previous studies in 
the past decade have shown that, individually, these metals often enhance biogas production at certain concentrations [7-9,15]. However, most of the studies were focused on the general performances, i.e., biogas yields in the presence of single or mixed metals.

Early studies found <10-160, 700-2800, 65-180 and 50-630 $\mu \mathrm{g} / \mathrm{g} \mathrm{Cu}, \mathrm{Fe}, \mathrm{Ni}$ and $\mathrm{Zn}$, respectively in methanogens (including 10 species of Methanosarcina, Methanococcus, Methanobacterium, and Methanobrevibacter, etc.) [16]. After investigation of the uptake and mass balance of trace metals for $\mathrm{CH}_{4}$ producing bacteria, Zhang et al. suggest that the contents of $\mathrm{Cu}, \mathrm{Fe}, \mathrm{Ni}$ and $\mathrm{Zn}$ in fermentation liquid should be greatly increased to get a high productivity of $\mathrm{CH}_{4}$ fermentation [17]. However, at relatively high concentrations, $\mathrm{Cu}$ inhibits substrate degradation and microbial growth as it alters the physiological steady state of the fermentation process [18,19]. In the methanogenic upflow anaerobic sludge blanket (UASB) granule, $\mathrm{Cu}$ has been shown to be more toxic than chromium (Cr), cadmium (Cd), $\mathrm{Zn}, \mathrm{Ni}$ and lead $(\mathrm{Pb})$ to volatile fatty acid (VFA)-degrading organisms [11].

Since almost every metalloenzyme involved in the pathway of biogas production contains multiple $\mathrm{Fe}_{2} \mathrm{~S}_{2}, \mathrm{Fe}_{3} \mathrm{~S}_{4}$, or $\mathrm{Fe}_{4} \mathrm{~S}_{4}$ clusters, Fe is essential for biogas production [20-22]. The addition of Fe often stimulates biogas production by extending the gas production peak and enhancing cellulase activities [7]. The addition of $1500 \mathrm{mg} / \mathrm{L} \mathrm{Cu} \mathrm{Fe-based} \mathrm{bimetallic} \mathrm{nanoparticles} \mathrm{(nZVI/Cu)} \mathrm{increased}$ biogas production three times the control (no nZVI/Cu added) [23].

Most prosthetic groups in bacterial and archaeal enzymes contain Ni [24]. For example, $\mathrm{CO}$ dehydrogenase $(\mathrm{CODH})$, a key enzyme in conversion of acetate to biogas, contains a Ni/Fe-S and a corrinoid/Fe-S component $[25,26]$. The enzymatic reduction of methyl coenzyme $\mathrm{M}_{\text {to }} \mathrm{CH}_{4}$ during methanogenesis by Methyl-coenzyme $\mathrm{M}$ reductase (MCR), an enzyme exclusively found in methanogenic archaea [27], involves a Ni containing cofactor called $F_{430}[21,26,28]$. Hence, Ni addition has been shown to increase the cumulative biogas yields by improving the efficiency of the first peak stage as well as bringing forward the second peak stage [9]. Ni was previously shown to act synergistically in $\mathrm{Ni}-\mathrm{Cu}, \mathrm{Ni}-\mathrm{Mo}-\mathrm{Co}$ and $\mathrm{Ni}-\mathrm{Hg}$ systems but antagonistically in Ni-Cd and Ni-Zn systems (as reviewed by [29]). In contrast, Zn addition has been shown to be beneficial to enzymes required for acetoclastic and hydrogenotrophic $\mathrm{CH}_{4}$ production [15].

Considering the ubiquity of metal contamination, understanding the impact of metal mixtures on anaerobic fermentation is imperative in assessing their effect on waste minimization and biogas production. However, mechanistic investigations on the effects of combinations of $\mathrm{Cu}, \mathrm{Fe}, \mathrm{Ni}$ and $\mathrm{Zn}$ on the anaerobic fermentation process remain scarce. Therefore, the purpose of this study was to assess the impact of $\mathrm{Fe}, \mathrm{Ni}$ and $\mathrm{Zn}$ on the anaerobic fermentation of $\mathrm{Cu}$-containing waste biomass (i.e., mixed corn stover and cow dung). We evaluated the effect of metal mixtures on biogas properties, process stability, substrate degradation, enzyme activity as well as the microorganisms, in particularly methanogens during the fermentation process. 
Table 1. Previous studies about the impact of $\mathrm{Cu}, \mathrm{Fe}, \mathrm{Ni}$ and $\mathrm{Zn}$ on anaerobic fermentation.

\begin{tabular}{|c|c|c|c|c|c|c|c|}
\hline Feedstocks & Metals & Reactor Type and Volume & Temp $\left({ }^{\circ} \mathrm{C}\right)$ & HRT (d) & Biogas Yield & $\mathrm{CH}_{4}$ Yield & References \\
\hline Phragmites straw + Cow dung & $\mathrm{Cu}$ & Pilot (30 L) & $37 \pm 1$ & 33 & $110.59 \mathrm{~mL} / \mathrm{gTS}$ & Maximum $86.72 \%$ & [8] \\
\hline Phytolacca americana $\mathrm{L}$. & $\mathrm{Cu}$ & Batch $(0.7 \mathrm{~L})$ & 37 & 50 & $0.12 \mathrm{~L} / \mathrm{gVS}$ & $52 \%$ & [30] \\
\hline Zea mays L. & $\mathrm{Cu}$ & Batch (0.7 L) & 37 & 50 & $0.45 \mathrm{~L} / \mathrm{gVS}$ & $\sim 70 \%$ & [30] \\
\hline Brassica napus L. & $\mathrm{Cu}$ & Batch $(0.7 \mathrm{~L})$ & 37 & 50 & $0.40 \mathrm{~L} / \mathrm{gVS}$ & $\sim 70 \%$ & [30] \\
\hline Elsholtzia splendens & $\mathrm{Cu}$ & Batch (0.7 L) & 37 & 50 & $0.27 \mathrm{~L} / \mathrm{gVS}$ & $56 \%$ & [30] \\
\hline Oenothera biennis L. & $\mathrm{Cu}$ & Batch $(0.7 \mathrm{~L})$ & 37 & 50 & $0.39 \mathrm{~L} / \mathrm{gVS}$ & $56 \%$ & [30] \\
\hline Phragmites straw + Cow dung & $\mathrm{Fe}$ & Batch $(0.25 \mathrm{~L})$ & $35 \pm 1$ & 26 & $26.20-32.46 \mathrm{~mL} / \mathrm{gTS}$ & Maximum $67.9 \%$ & [7] \\
\hline Lemnaceae + Poultry manure & $\mathrm{Fe}$ & Batch (1 L) & $32 \pm 2$ & $50-80$ & $0.281 \mathrm{~L} / \mathrm{g}$ VS & $65-80 \%$ & [31] \\
\hline Lemnaceae + Poultry manure & $\mathrm{Fe}$ & Semi-cont. (25 L) & $32 \pm 2$ & $8.3-16.6$ & $22.76 \mathrm{~L} / \mathrm{d}$ & NR & [31] \\
\hline $\begin{array}{l}\text { Synthetic model substrate for } \\
\text { maize silage }\end{array}$ & $\mathrm{Ni}$ & Batch (1 L) & 35 & 30 & NR & $\begin{array}{c}188-404 \mathrm{~L}_{\mathrm{N}} / \mathrm{kg} \text { organic } \\
\text { dry matter }\end{array}$ & [32] \\
\hline Model substrate for maize & $\mathrm{Ni}$ & Semi-cont. (5 L) & 35 & $\sim 60$ & $0.6-8.0 \mathrm{~L}_{\mathrm{N}} / \mathrm{d}$ & $36-55 \%$ & [33] \\
\hline Phragmites straw + Cow dung & $\mathrm{Ni}$ & Batch $(0.25 \mathrm{~L})$ & $35 \pm 1$ & 26 & $27.49-32.70 \mathrm{~mL} / \mathrm{gTS}$ & Maximum $70.41 \%$ & [9] \\
\hline Azolla pinnata R.Br & $\begin{array}{c}\mathrm{Fe}, \mathrm{Cu}, \mathrm{Cd}, \mathrm{Ni}, \mathrm{Pb}, \mathrm{Zn}, \mathrm{Mn} \text { and } \\
\mathrm{Co}\end{array}$ & Batch (2 L) & 37 & $36-42$ & $132-189 \mathrm{~L} / \mathrm{kg}$ & $45-83 \%$ & [10] \\
\hline Lemna minor L. & $\begin{array}{c}\mathrm{Fe}, \mathrm{Cu}, \mathrm{Cd}, \mathrm{Ni}, \mathrm{Pb}, \mathrm{Zn}, \mathrm{Mn} \text { and } \\
\mathrm{Co}\end{array}$ & Batch $(2 \mathrm{~L})$ & 37 & $36-42$ & $132-176 \mathrm{~L} / \mathrm{kg}$ & $43-85 \%$ & [10] \\
\hline Seaweed & $\mathrm{Cd}, \mathrm{Cu}, \mathrm{Ni}, \mathrm{Zn}$ & Batch $(0.5 \mathrm{~L})$ & 37 & 30 & NR & $\begin{array}{c}0.09-0.12 \mathrm{~L}_{\mathrm{N}} \mathrm{CH}_{4} / \mathrm{g} \text { VSa } \\
(44.4-49.7 \%) \\
\end{array}$ & [34] \\
\hline Seaweed & $\mathrm{Cd}, \mathrm{Cu}, \mathrm{Ni}, \mathrm{Zn}$ & UASB $(0.8 \mathrm{~L})$ & $37 \pm 1$ & $8.8-0.5$ & $0.22-3.04 \mathrm{~L}_{\mathrm{N}} \mathrm{CH}_{4} / \mathrm{L} \cdot \mathrm{d}$ & $\begin{array}{c}0.16-0.23 \mathrm{~L}_{\mathrm{N}} \mathrm{CH}_{4} / \mathrm{g} \mathrm{CODa} \\
(62.9-73.7 \%)\end{array}$ & [34] \\
\hline Triticale & $\mathrm{Al}, \mathrm{Ni}, \mathrm{Zn}, \mathrm{Co}, \mathrm{U}, \mathrm{La}$ & Stirring reactor $(5 \mathrm{~L})$ & $38 \pm 1$ & NR & $\sim 780 \mathrm{~L}_{\mathrm{N}} / \mathrm{kgVS}$ & $440 \mathrm{~L}_{\mathrm{N}} / \mathrm{kgVS}$ & [35] \\
\hline Brassica juncea & $\mathrm{Al}, \mathrm{Ni}, \mathrm{Zn}, \mathrm{Co}, \mathrm{U}, \mathrm{La}$ & Stirring reactor $(5 \mathrm{~L})$ & $38 \pm 1$ & NR & $\sim 640 \mathrm{~L}_{\mathrm{N}} / \mathrm{kgVS}$ & $425 \mathrm{~L}_{\mathrm{N}} / \mathrm{kgVS}$ & [35] \\
\hline Helianthus annuus & $\mathrm{Al}, \mathrm{Ni}, \mathrm{Zn}, \mathrm{Co}, \mathrm{U}, \mathrm{La}$ & Stirring reactor $(5 \mathrm{~L})$ & $38 \pm 1$ & NR & $\sim 360 \mathrm{~L}_{\mathrm{N}} / \mathrm{kgVS}$ & $163 \mathrm{~L}_{\mathrm{N}} / \mathrm{kgVS}$ & [35] \\
\hline Eichhornia crassipes & $\begin{array}{l}\mathrm{Cu} \text { - and } \mathrm{Cr} \text {-rich brass and } \\
\text { electroplating industry effluent }\end{array}$ & Batch (NR) & $35 \pm 1$ & 20 & $11.10-27.80 \mathrm{~L} / \mathrm{kg} \mathrm{dw}$ & $29.80-63.82 \%$ & [36] \\
\hline Trapa bispinnosa & $\begin{array}{l}\mathrm{Cu} \text { - and } \mathrm{Cr} \text {-rich brass and } \\
\text { electroplating industry effluent }\end{array}$ & Batch $(>0.15 \mathrm{~L})$ & $35 \pm 1$ & 20 & $10.45-20.90 \mathrm{~L} / \mathrm{kg} \mathrm{dw}$ & $27.00-57.04 \%$ & [36] \\
\hline
\end{tabular}

NR—not reported; HRT—hydraulic retention time; Semi-cont, semi-continuous reactors; UASB—upflow anaerobic sludge blanket; TS—-total solid; VS—volatile solid. 


\section{Materials and Methods}

\subsection{Experimental Materials}

Corn stover collected from the farmland in Tongzhou, Beijing, China, in November 2016, was used as the feedstock. The corn stover was harvested by cutting $10 \mathrm{~cm}$ above the ground, then diced into pieces 5-10 cm in length, and then air dried until moisture levels were below 10\%. After drying, the stover was ground into powder and passed through a 10-mesh sieve. Fresh cow dung collected from the Yanqing base, Beijing Dairy Cattle Centre, was mixed with stover as part of the feedstock and as the microbial inoculum. Prior to feeding to the reactor, the fresh cow dung was stored at $4.0^{\circ} \mathrm{C}$. No additional inoculum was used to initiate the fermentation. Table 2 shows the characteristics of the corn stover and the cow dung. Section 2.3 provides a description of the methods used to determine these physicochemical characteristics.

Table 2. Characteristics of corn stover and the cow dung.

\begin{tabular}{ccc}
\hline Characteristics & Corn Stover & Fresh Cow Dung \\
\hline TS (\%dry weight) & $95.59 \pm 0.23$ & $16.49 \pm 0.16$ \\
VS $(\%$ TS) & $90.72 \pm 0.24$ & $84.00 \pm 0.48$ \\
TN $(\%$ TS) & $1.21 \pm 0.03$ & $3.22 \pm 0.11$ \\
TOC $(\% \mathrm{TS})$ & $13.94 \pm 0.64$ & $14.81 \pm 0.37$ \\
Ratio of C/N & $11.52 \pm 0.05$ & $4.45 \pm 0.30$ \\
Cellulose $(\%$ TS $)$ & $20.19 \pm 1.24$ & $23.56 \pm 1.47$ \\
Hemicellulose $(\%$ TS $)$ & $14.05 \pm 2.25$ & $16.41 \pm 0.48$ \\
Lignin $(\%$ TS $)$ & $13.55 \pm 0.07$ & $15.41 \pm 1.11$ \\
Cu $(\mu \mathrm{g} / \mathrm{g})$ & $8.57 \pm 0.20$ & $38.63 \pm 0.30$ \\
Ni $(\mu \mathrm{g} / \mathrm{g})$ & $1.71 \pm 0.37$ & $1.78 \pm 0.10$ \\
Cd $(\mu \mathrm{g} / \mathrm{g})$ & Negligible & Negligible \\
Zn $(\mu \mathrm{g} / \mathrm{g})$ & $14.89 \pm 1.61$ & $152.44 \pm 2.06$ \\
Fe $(\mu \mathrm{g} / \mathrm{g})$ & $520.80 \pm 67.03$ & $610.80 \pm 12.87$ \\
Co $(\mu \mathrm{g} / \mathrm{g})$ & $0.34 \pm 0.24$ & $0.61 \pm 0.03$ \\
Cr $(\mu \mathrm{g} / \mathrm{g})$ & $8.33 \pm 1.13$ & $3.01 \pm 0.63$ \\
\hline
\end{tabular}

Mean \pm Standard Error. $n=3$. TS—-total solid; VS—volatile solid; TN—total nitrogen; TOC—total organic carbon.

\subsection{Anaerobic Fermentation Experiment}

Experiments were conducted in anaerobic fermenters (30 L total volume and $20 \mathrm{~L}$ available volume, YGF 300/30, Shanghai Yangge Biological Engineering Equipment Co., Ltd., Shanghai, China) for 28 days at $55 \pm 1.0{ }^{\circ} \mathrm{C}$ (auto controlled) as previously reported [5]. Prior to each experiment, the fermenters were cleaned and autoclaved. The digester contents were thoroughly stirred using a three-layer stirrer introduced in the middle of each fermenter for $30 \mathrm{~min}$ prior to sampling and measuring physicochemical parameters.

The feedstocks were comprised of a mixture of corn stover ( $0.8 \mathrm{~kg}$ dry weight) and cow dung (0.8 kg dry weight). The total solids (TSs) of the substrate in the fermenters was adjusted to $8 \%$ by adding distilled water. At the beginning of fermentation, $10.0 \mathrm{mg} \mathrm{Cu} / \mathrm{L}\left(0.536 \mathrm{~g} \mathrm{of} \mathrm{CuCl}_{2} \cdot 2 \mathrm{H}_{2} \mathrm{O}\right)$ was added into four fermenters. Approximately $10.0 \mathrm{mg} \mathrm{Fe} / \mathrm{L}, 2.0 \mathrm{mg} \mathrm{Ni} / \mathrm{L}$, and $2.0 \mathrm{mg} \mathrm{Zn/L} \mathrm{were} \mathrm{added}$ to three of the fermenters by adding $0.712 \mathrm{~g} \mathrm{FeCl}_{2} \cdot 4 \mathrm{H}_{2} \mathrm{O}, 0.162 \mathrm{~g} \mathrm{NiCl}_{2} \cdot 6 \mathrm{H}_{2} \mathrm{O}$ and $0.083 \mathrm{~g} \mathrm{ZnCl}_{2}$, respectively. There were four treatments with $10.0 \mathrm{mg} / \mathrm{L} \mathrm{Cu}(\mathrm{Cu}$ treatment), $10.0 \mathrm{mg} / \mathrm{L} \mathrm{Cu}$ with 10.0 $\mathrm{mg} / \mathrm{L} \mathrm{Fe}(\mathrm{Cu}+\mathrm{Fe}$ treatment $), 10.0 \mathrm{mg} / \mathrm{L} \mathrm{Cu}$ with $2.0 \mathrm{mg} / \mathrm{L} \mathrm{Ni}(\mathrm{Cu}+\mathrm{Ni}$ treatment$)$ and $10.0 \mathrm{mg} / \mathrm{L}$ $\mathrm{Cu}$ with $2.0 \mathrm{mg} / \mathrm{L} \mathrm{Zn}(\mathrm{Cu}+\mathrm{Zn}$ treatment). These concentrations of the metals were suggested to be stimulatory for biogas production according to the previous studies [7-9] and pre-experiments. Finally, the fermenters were purged with $\mathrm{N}_{2}$ gas for 5 min to remove oxygen. 


\subsection{Chemical and Microbial Analyses}

Biogas yields and $\mathrm{pH}$ values were automatically measured at 09:00 h every day [8]. Solid, liquid and gas samples were collected every three days at 09:00. TSs were measured by weighing the samples after drying at $105^{\circ} \mathrm{C}$ for $24 \mathrm{~h}$. Volatile solids (VSs) were measured after treating the samples in a muffle furnace at $550^{\circ} \mathrm{C}$ for $1 \mathrm{~h}$. Total nitrogen (TN) was measured by the indophenol blue colorimetric method after being digested by concentrated sulfuric acid and 30\% hydrogen peroxide [37]. Total organic carbon (TOC) was measured by potassium dichromate volumetric method [37]. Cellulose, hemicellulose and lignin in solid were determined by cellulose, hemicellulose and lignin Enzyme-Linked Immunosorbent Assays kit (ELISA, Qingdao Kebiao Testing and Research Institute Co. LTD, Qingdao, China), respectively. Chemical oxygen demand (COD) in the supernatant was obtained by the potassium dichromate method after sample centrifugation at $5000 \mathrm{rpm}$ for $10 \mathrm{~min}$. Ammonia nitrogen $\left(\mathrm{NH}_{4}{ }^{+} \mathrm{N}\right)$ was measured by Nessler's reagent method [38]. The cellulase and coenzyme $F_{420}$ activities in the supernatant were determined according to the standard method after centrifugation at $4000 \mathrm{rpm}$ for 5 min [39]. The coenzyme M was measured by botany coenzyme M ELISA kit (Qingdao Kebiao Testing and Research Institute co. LTD). Samples for VFA analysis were passed through a $0.45-\mu \mathrm{m}$ nitrocellulose membrane filter and frozen prior to analysis. The concentrations of VFAs were measured using a gas chromatograph (GC-2014, Shimadzu Co., Kyoto, Japan) with a flame ionization detector (FID). Standards of $\mathrm{C} 2-\mathrm{C} 5$ fatty acids (chromatographically pure) were used for quantification. The VFA concentration was expressed as $\mathrm{mg} / \mathrm{L}$ of individual species ( $\mathrm{C} 2-\mathrm{C} 5$ fatty acids). $\mathrm{CH}_{4}$ contents in biogas were measured by a gas chromatograph (GC-2014C, Shimadzu Co., Japan) equipped with a GDX-401 column with $\mathrm{H}_{2}$ as the carrier gas. Detection was performed with a thermal conductivity detector (TCD).

The measurement of microbial sequences were conducted by the Novogene Co. Ltd. (Beijing, China) after centrifuging the samples at $8000 \mathrm{rpm}$ and $4{ }^{\circ} \mathrm{C}$ for $3 \mathrm{~min}$. Briefly, the genomic DNA of the samples on the 7th, 13th and 19th day were extracted by the Cetyltrimethylammonium Ammonium Bromide (CTAB) method [40]. After the extraction, the samples were diluted to a concentration of $1 \mathrm{ng} / \mathrm{L}$ with sterile water. Then the diluted genomic DNA was used as the template for PCR amplification. PCR amplification of the V3-V4 hypervariable region of bacterial $16 \mathrm{~S}$ rDNA was performed using universal primers 338F (5'-ACTCCTACGGGAGGCAGCAG-3') and 806R (5'-GGACTACHVGGGTWTCTAAT-3') [41]. The archaeal primers used to amplify the V3-V4 hypervariable region of archaeal $16 \mathrm{~S}$ rDNA were 344F (5'-ACGGGGYGCAGCAGGCGCGA-3') and 806R (5'-GGACTACVSGGGTATCTAAT-3'). All primers included Illumina barcode sequences for multiplexing each sample. The library construction was conducted with TruSeq ${ }^{\circledR}$ DNA PCR-Free Sample Preparation Kit. After the Qubit and Q-PCR quantification, the constructed library was qualified and HiSeq2500 PE250 was used for sequencing. The obtained sequencing data were stored in Fastq files.

\subsection{Data Analysis}

After removing the barcode and primers' sequences from the sequencing data (FASTQ files), the reads were matched with fast length adjustment of short reads software (FLASH, V1.2.7, http: //www.cbcb.umd.edu/software/flash) for raw Tags and then sieved for clean Tags. Clean Tags were cut out and the lengths filtered by referencing the quantitative insights into microbial ecology (QIIME V1.9.1, http://qiime.org/scripts/split_libraries_fastq.html) quality control process. The obtained Tags were treated by removing the chimeric sequence through comparison with the detection chimeric sequence (Gold database) yielding the final effective Tags as the targets. The cluster analysis of effective Tags was conducted using Uparse software (V7.0.1001, http://drive5.com/uparse/). The operational taxonomic units (OTUs) were clustered with identity $>97 \%$. Species annotation of the OTUs representative sequence was carried out using Mothur method and SSUrRNA database (define threshold of 0.8-1.0). The microbial communities were then obtained after annotation.

The data in the study were the average of triplicate treatments. Error bars represent the standard errors of the mean: $\mathrm{SEM}=\mathrm{SD} / \sqrt{\mathrm{n}}$, where $\mathrm{SD}$ is the standard deviation. One-way analysis of variance 
(One-Way ANOVA) and Pearson correlation analysis were performed in the Statistical Package for the Social Science (SPSS, 17.0, Chicago, IL, USA) software at 0.05 and 0.01 levels of significance represented by $*(p<0.05)$ and ${ }^{* *}(p<0.01)$, respectively.

\section{Results and Discussion}

\subsection{Biogas Properties of $\mathrm{Cu}$-Treated Fermenters Combining with Fe, Ni and $\mathrm{Zn}$}

\subsubsection{Biogas Yields}

Figure 1a shows the impact of $\mathrm{Fe}, \mathrm{Ni}$ and $\mathrm{Zn}$ combined with $\mathrm{Cu}$ addition on cumulative biogas yields. For the $\mathrm{Cu}$ treatment, cumulative biogas yields were $279.46 \pm 2.29 \mathrm{~mL} / \mathrm{g}$ TS, which was much higher than the yields of anaerobic fermentation with Phragmites straw and cow dung as feedstock under $37.0 \pm 1.0^{\circ} \mathrm{C}$ [8]. The $\mathrm{Cu}+\mathrm{Ni}$ treatment produced more biogas than other treatments while the $\mathrm{Cu}$ treatment obtained the lowest biogas yields. The cumulative biogas yields of $\mathrm{Cu}+\mathrm{Ni}, \mathrm{Cu}+\mathrm{Fe}$ and $\mathrm{Cu}+\mathrm{Zn}$ treatments were 53.33, 27.27 and $17.80 \%$, respectively, which were higher than the $\mathrm{Cu}$ treatment. Thus, combining $\mathrm{Fe}, \mathrm{Ni}$ and $\mathrm{Zn}$ with $\mathrm{Cu}$ promoted biogas production.

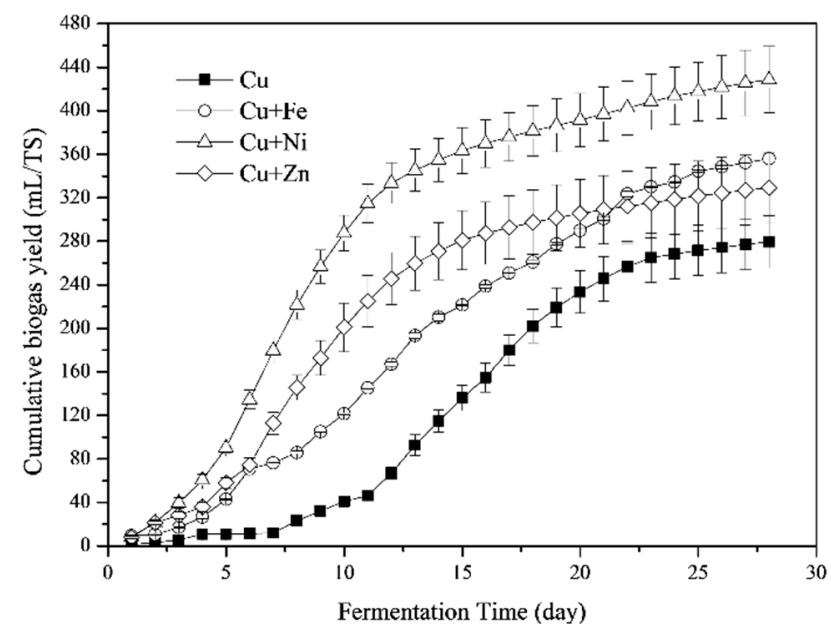

(A)

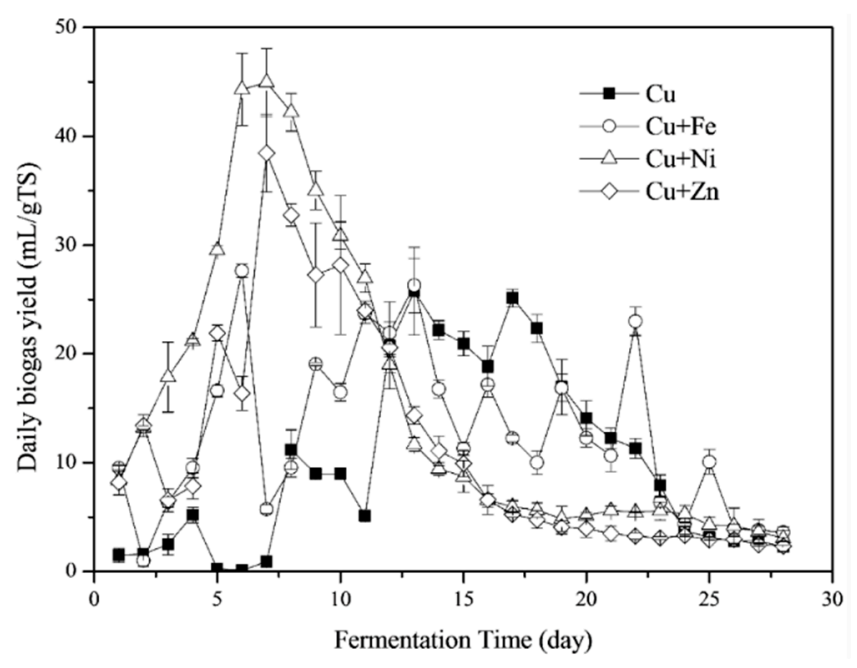

(B)

Figure 1. Cont. 


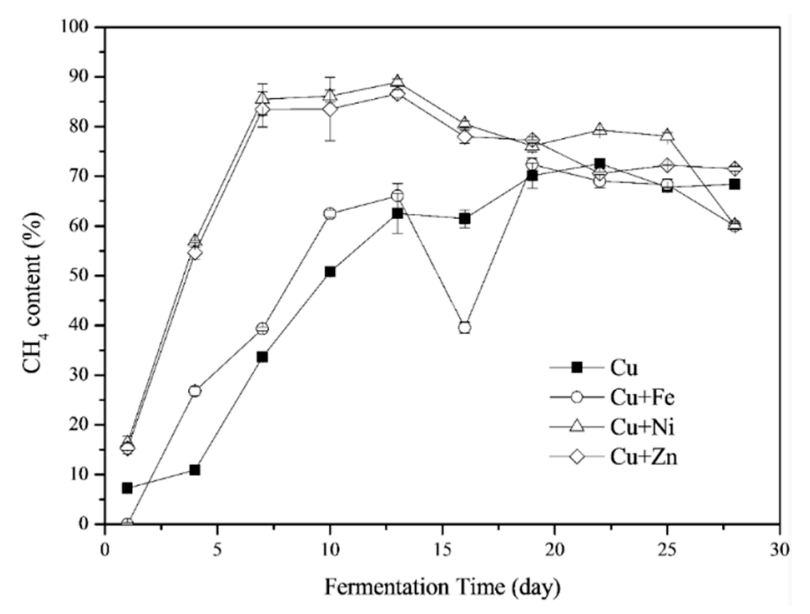

(C)

Figure 1. Cumulative biogas yields (A); daily biogas yields (B); and $\mathrm{CH}_{4}$ contents (C) during the fermentation process with combination of $\mathrm{Cu}$ and $\mathrm{Fe}, \mathrm{Ni}$ and $\mathrm{Zn}$.

The stimulatory effect of combining metals on daily biogas yields were high during the initial 12 days of the fermentation period (Figure $1 \mathrm{~b}$ ). The highest daily biogas yields were 25.76, 27.63, 44.95 and $38.45 \mathrm{~mL} / \mathrm{g}$ TS for $\mathrm{Cu}, \mathrm{Cu}+\mathrm{Fe}, \mathrm{Cu}+\mathrm{Ni}$ and $\mathrm{Cu}+\mathrm{Zn}$ treatments, respectively. Distinctively high daily biogas peaks for $\mathrm{Cu}+\mathrm{Ni}$ and $\mathrm{Cu}+\mathrm{Zn}$ treatments on the 7 th day were observed. The $\mathrm{Cu}+\mathrm{Fe}$ and $\mathrm{Cu}$ treatments showed significant variations during the fermentation process. Despite yielding the lowest biogas, after the 11th day, the $\mathrm{Cu}$ treatment had a sharp increase in cumulative biogas yields as shown in Figure 1a. These results show that the addition of $\mathrm{Fe}, \mathrm{Ni}$ and $\mathrm{Zn}$ into the $\mathrm{Cu}$-containing anaerobic fermentation system could enhance the yield and quicken the daily biogas peak. Furthermore, these results explained the different growth process of cumulative biogas yields in the metal mixtures treatments. According to the previous studies, the growth process of cumulative biogas yields was generally expressed as a diauxie growth for those fermentation process with straw and cow dung as feedstocks when there was no metal added or one kind of metal added [2,5,7-9]. In the present study, the growth process in the $\mathrm{Cu}$ treatment was diauxie, while that in the $\mathrm{Cu}+\mathrm{Fe}, \mathrm{Cu}+\mathrm{Ni}$ and $\mathrm{Cu}+\mathrm{Zn}$ treatments was one-phase decomposition since the second biogas peak was brought forward and occurred together with the first one.

\subsection{2. $\mathrm{CH}_{4}$ Yields}

The highest $\mathrm{CH}_{4}$ contents were 72.57, 72.41, 88.94 and $86.58 \%$ for $\mathrm{Cu}, \mathrm{Cu}+\mathrm{Fe}, \mathrm{Cu}+\mathrm{Ni}$ and $\mathrm{Cu}+\mathrm{Zn}$ treatments, respectively. On the 1st day of fermentation, $\mathrm{CH}_{4}$ contents were low in the $\mathrm{Cu}$ and $\mathrm{Cu}+\mathrm{Fe}$ treatments (Figure 1c). In contrast, the $\mathrm{Cu}+\mathrm{Ni}$ and $\mathrm{Cu}+\mathrm{Zn}$ treatments had a higher $\mathrm{CH}_{4}$ content, suggesting $\mathrm{Ni}$ and $\mathrm{Zn}$ probably accelerated the initiation of the fermentation process. The $\mathrm{CH}_{4}$ contents of the $\mathrm{Cu}$ - treatments gradually increased, equaling $\mathrm{Cu}+\mathrm{Fe}$ treatment after 13 days and then $\mathrm{Cu}+\mathrm{Zn}$ after 22 days. The $\mathrm{CH}_{4}$ contents in $\mathrm{Cu}+\mathrm{Ni}$ and $\mathrm{Cu}+\mathrm{Zn}$ treatments were similar from the 1st day to the 23 rd day, marked by a rapid increase in the first 7 days and then plateauing until the 13th day, followed by a gradual decrease. $\mathrm{CH}_{4}$ contents in the $\mathrm{Cu}$ treatment were similar with the previous study, in which 30 and $100 \mathrm{mg} / \mathrm{L} \mathrm{Cu}$ addition resulted in a $\mathrm{CH}_{4}$ content of 86.72 and $77.35 \%$, respectively [8]. Moreover, $\mathrm{CH}_{4}$ contents in $\mathrm{Cu}+\mathrm{Fe}$ and $\mathrm{Cu}+\mathrm{Ni}$ groups were higher than that in $\mathrm{Fe}(67.90 \%)$ and $\mathrm{Ni}(70.41 \%)$ experiments [7,9]. Therefore, the addition of $\mathrm{Cu}$ improved $\mathrm{CH}_{4}$ production and further addition of $\mathrm{Ni}$ and $\mathrm{Zn}$ enhanced the stimulatory effect.

\subsection{Process Stability as Indicated by the Variation of $p H$ Values}

$\mathrm{pH}$ values increased slightly after the fermentation started (Figure 2). There was considerable fluctuation in $\mathrm{pH}$ values from the $\mathrm{Cu}$ - and $\mathrm{Cu}+\mathrm{Fe}$ treatments. The $\mathrm{pH}$ increased remarkably after the 
11th and 10th day, respectively. After the two-day surge, $\mathrm{pH}$ values in these two treatments decreased slightly and then increased again until it stabilized at a $\mathrm{pH}$ of 7.54 and 7.35 in the $\mathrm{Cu}$ and $\mathrm{Cu}+\mathrm{Fe}$ treatments, respectively. A similar trend was reported in previous research [8]. For $\mathrm{Cu}+\mathrm{Ni}$ and $\mathrm{Cu}+\mathrm{Zn}$ treatments, $\mathrm{pH}$ values decreased after the 1 st day and recovered after the 5 th day. The increase in $\mathrm{pH}$ values in these two groups decreased after the 7th and 8 th day with the final $\mathrm{pH}$ values plateauing at around 7.35 and 7.77 , respectively.

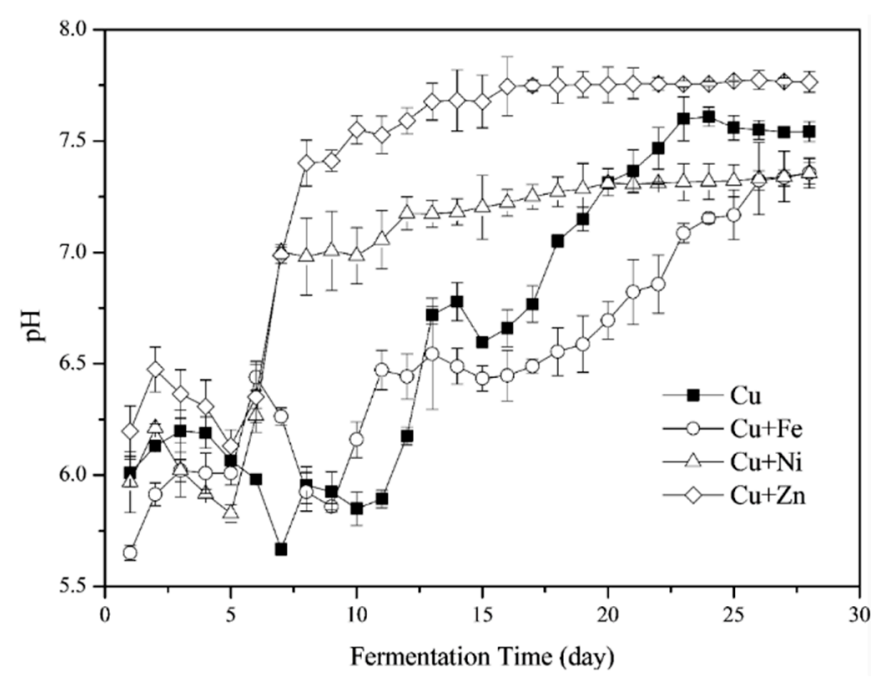

Figure 2. The $\mathrm{pH}$ values following the addition of $\mathrm{Cu}$ together with $\mathrm{Fe}, \mathrm{Ni}$, or $\mathrm{Zn}$ during the fermentation process.

Taking the whole process into account, $\mathrm{pH}$ values for all the four treatments were generally located in the optimal $\mathrm{pH}$ ranges for the function of most methanogenic bacteria [42]. Moreover, Fe addition did not change the $\mathrm{pH}$ variation while $\mathrm{Ni}$ and $\mathrm{Zn}$ addition benefited the process stability. However, in some studies the $\mathrm{pH}$ values decreased during the initiation of the fermentation process probably due to accumulation of the acidic components hydrolyzed from organic materials [5,8]. In this study, the feedstocks were efficiently used for methanogenesis with no accumulation of acidic components.

\subsection{Substrate Biodegradation}

\subsubsection{Variations of Ammonia Nitrogen $\left(\mathrm{NH}_{4}{ }^{+}-\mathrm{N}\right)$ Concentrations}

Total ammonia, consisting of ammonium ions and free ammonia, is produced during the anaerobic degradation of proteins, urea, and nucleic acids [43]. It is a basic nutrient for microorganism growth at $\mathrm{NH}_{4}{ }^{+}-\mathrm{N}$ concentrations below $200 \mathrm{mg} / \mathrm{L}$ [44]. However, it has been shown that $\mathrm{NH}_{4}{ }^{+}-\mathrm{N}$ concentrations ranging from 0.6 to $14 \mathrm{~g} / \mathrm{L}$ inhibited the methanogenic activity (reported by [45] and reviewed by [29]) depending on different experimental conditions [46]. The effects of combining metals on $\mathrm{NH}_{4}{ }^{+}-\mathrm{N}$ concentrations during the fermentation process are shown in Figure 3a. The average $\mathrm{NH}_{4}{ }^{+}-\mathrm{N}$ concentrations were $476.63 \pm 37.36,652.83 \pm 61.88,569.31 \pm 23.62$ and $671.82 \pm 43.40 \mathrm{mg} / \mathrm{L}$ for $\mathrm{Cu}$, $\mathrm{Cu}+\mathrm{Fe}, \mathrm{Cu}+\mathrm{Ni}$ and $\mathrm{Cu}+\mathrm{Zn}$ treatments, respectively. Thus, $\mathrm{NH}_{4}{ }^{+}-\mathrm{N}$ concentrations in the present study were not likely to inhibit biogas production.

Compared to the previous study, in the presence of $\mathrm{Cu}$, the $\mathrm{NH}_{4}{ }^{+}-\mathrm{N}$ concentration in this study was higher than that with Phragmites straw and cow dung as feedstocks [8]. On one hand, the nitrogen content in the cow dung was higher in this study (Table 2). On the other hand, the Phragmites straw in the previous study was pretreated by acid, which reduced the $\mathrm{pH}$ values after the experiment started up and after the 15th day. Moreover, the $\mathrm{NH}_{4}{ }^{+}-\mathrm{N}$ concentration was reported to be positively correlated to $\mathrm{pH}$ values in the presence of $\mathrm{Cu}$ [47]. Therefore, the acidic environment as indicated by the reduced $\mathrm{pH}$ values in the previous study resulted in lower $\mathrm{NH}_{4}{ }^{+}-\mathrm{N}$ concentrations than the 
present study. Furthermore, the addition of $\mathrm{Fe}, \mathrm{Ni}$ and $\mathrm{Zn}$ benefited for the degradation of substrate containing nitrogen which contributed to the higher $\mathrm{NH}_{4}{ }^{+}-\mathrm{N}$ concentrations.

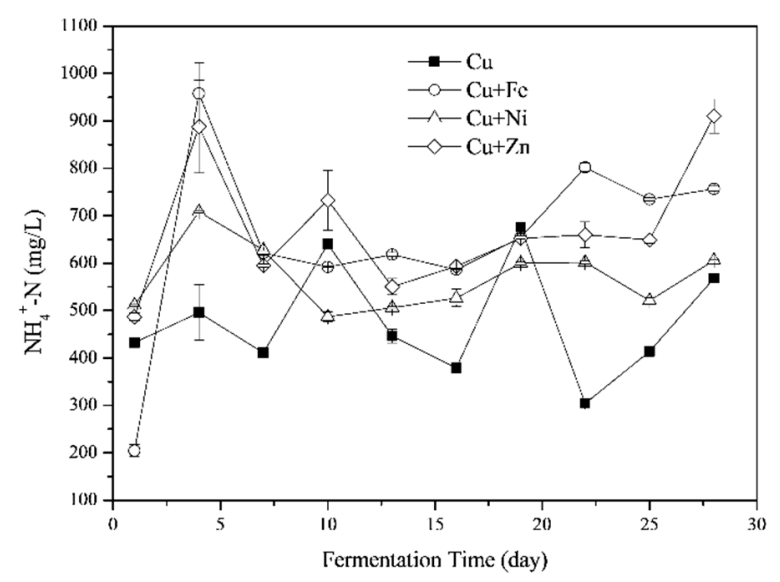

(A)

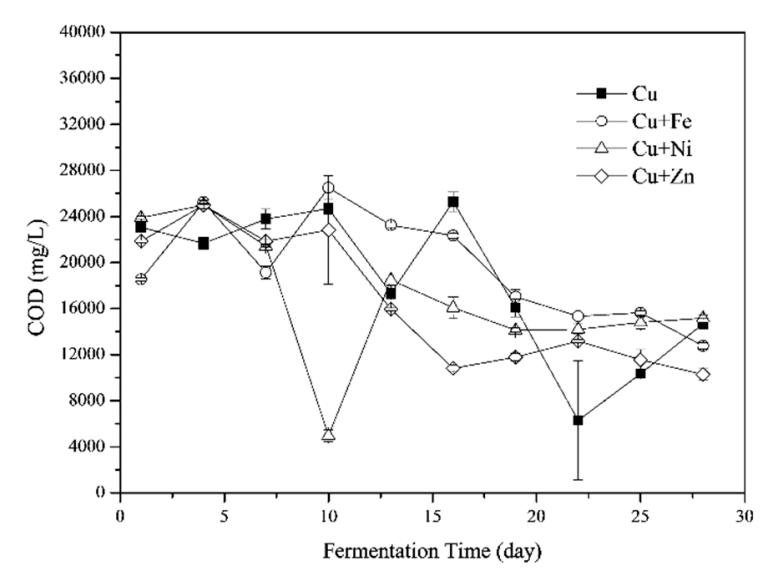

(B)

Figure 3. Ammonia nitrogen $\left(\mathrm{NH}_{4}{ }^{+}-\mathrm{N}\right)(\mathrm{A})$ and chemical oxygen demands (CODs) (B) during the fermentation process with $\mathrm{Fe}, \mathrm{Ni}$ and $\mathrm{Zn}$ addition combined with $\mathrm{Cu}$.

\subsubsection{Chemical Oxygen Demands (COD)}

The soluble organic components in the fermenter, shown as COD, originated from the hydrolysis of liquefied large molecules (i.e., long chain natural polymers of the substrate) by extracellular enzymes [22,48]. The impacts of combining metals addition on COD are shown in Figure $3 b$. In $\mathrm{Cu}$ treatment, COD was generally stable during the first 10 days of fermentation, which was different from the previous study [8], since the organic components in the liquor was efficiently used for $\mathrm{CH}_{4}$ production as proved by Figure $1 \mathrm{~b}$. The COD was then decreased in the later stage of fermentation, which indicated that organic components in the liquid phase were utilized for biogas production. COD of $\mathrm{Cu}+\mathrm{Fe}$ and $\mathrm{Cu}+\mathrm{Zn}$ treatments showed the same trend, while COD of $\mathrm{Cu}+\mathrm{Ni}$ treatment decreased sharply on the 10th day corresponding with the high VFA concentrations on the same day.

The average COD during the entire fermentation process was 18,323.99 \pm 2055.90 , $19,578.36 \pm 1448.09,16,816.34 \pm 1834.62$, and 16,508.78 $\pm 1821.49 \mathrm{mg} / \mathrm{L}$ for the $\mathrm{Cu}, \mathrm{Cu}+\mathrm{Fe}, \mathrm{Cu}+\mathrm{Ni}$ and $\mathrm{Cu}+\mathrm{Zn}$ treatments, respectively. The COD at the beginning of fermentation in $\mathrm{Cu}$ treatment was much higher than the previous study [8]. The possible explanation was the differences in feedstocks and fermentation temperatures. For the present study, the VS contents of the cow dung was higher than the previous study which indicated more organic matters available for microorganisms. Moreover, 
thermophilic fermentation generally induced higher metabolic rates than mesophilic fermentation. That is, the fermentation temperature of $55.0 \pm 1.0^{\circ} \mathrm{C}$ in this study resulted in more organic matters in the fermenter liquor than the previous study $\left(37.0 \pm 1.0^{\circ} \mathrm{C}\right)$ [8]. There was no significant difference between the treatments. Hence, the VFAs and other distinct components might be more sensitive to the impact of metal mixtures on the different stages of fermentation.

\subsubsection{Responses of Volatile Fatty Acids (VFAs)}

The total VFA concentrations and their compositions, i.e., acetic acid, propionic acid, butyric acid and valeric acid, are shown in Figure 4. As reported in a previous study [8], the total VFA concentrations were generally high at the early stage of fermentation and subsequently declined as the fermentation process progressed. However, the total VFA concentrations were generally lower than in the previous research [8]. This result was coincidedwith the higher biogas yields in this study, indicating the efficient utilization of VFAs for biogas production.

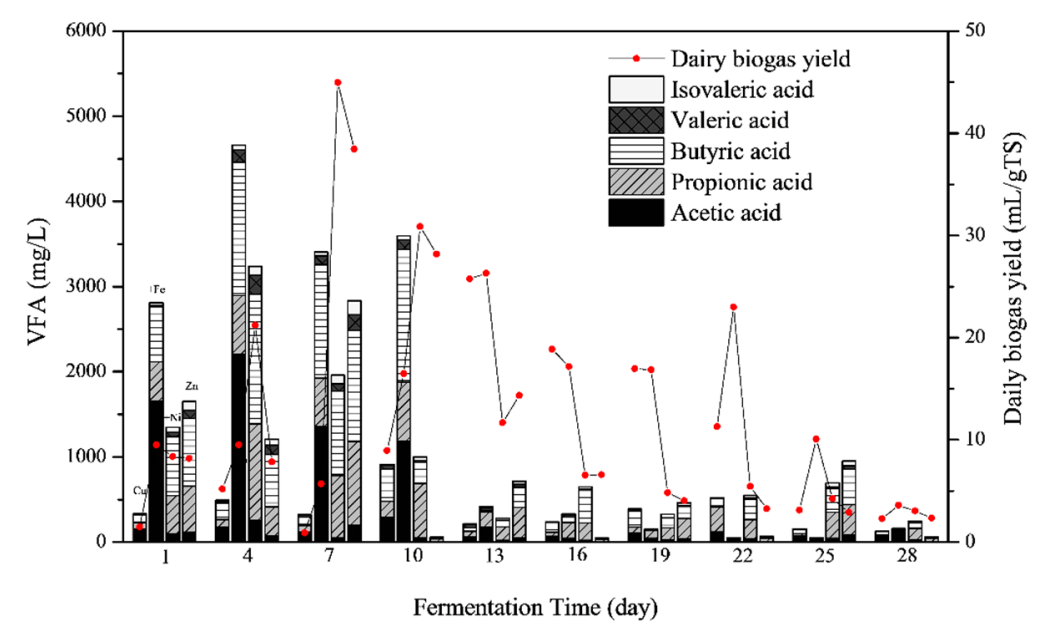

Figure 4. Volatile fatty acids (VFAs) concentrations in the liquid phase during the fermentation process. For each day, the column from left to right shows the VFA compositions of $\mathrm{Cu}, \mathrm{Cu}+\mathrm{Fe}, \mathrm{Cu}+\mathrm{Ni}$ and $\mathrm{Cu}+\mathrm{Zn}$ treatments, respectively. The compositions of VFA were shown by stacked bars in the order of acetic acid (black), propionic acid (bias), butyric acid (transverse) and valeric acid (grid) from bottom.

During the first 7 days, total VFA concentrations (which corresponded with higher biogas yields) of $\mathrm{Cu}+\mathrm{Fe}, \mathrm{Cu}+\mathrm{Ni}$ and $\mathrm{Cu}+\mathrm{Zn}$ treatments were higher than the $\mathrm{Cu}$ treatment (Figure $1 \mathrm{~b}$ ). This suggested that VFAs were more efficiently produced and consumed for biogas production in these treatments. During this period, the $\mathrm{pH}$ values remained high, since alkaline components such as $\mathrm{NH}_{4}{ }^{+}-\mathrm{N}$ were being generated. On the 10th day, an increase in the VFAs concentration and daily biogas yields in $\mathrm{Cu}$ and $\mathrm{Cu}+\mathrm{Fe}$ treatments was observed. In contrast, the limitation of VFAs in $\mathrm{Cu}+\mathrm{Ni}$ and $\mathrm{Cu}+\mathrm{Zn}$ treatments resulted in a decrease in the daily biogas yields (Figure 1b).

The main compositions of VFAs varied with metal addition. During the first 7 days, acetic acid was the main component, followed by butyric acid > propionic acid > valeric acid in the $\mathrm{Cu}$ and $\mathrm{Cu}+\mathrm{Fe}$ treatments. However, the order of the VFA components by amount was butyric acid >propionic acid > acetic acid $>$ valeric acid in $\mathrm{Cu}+\mathrm{Ni}$ and $\mathrm{Cu}+\mathrm{Zn}$ treatments. Acetic acid was efficiently used during methanogenesis; hence the higher biogas and $\mathrm{CH}_{4}$ yields in $\mathrm{Cu}+\mathrm{Ni}$ and $\mathrm{Cu}+\mathrm{Zn}$ treatments. After the 10th day, the concentrations of all VFA compositions in $\mathrm{Cu}+\mathrm{Ni}$ and $\mathrm{Cu}+\mathrm{Zn}$ treatments decreased. Moreover, the low efficiency of transferring C3-C5 VFAs into acetic acid limited biogas production. However, higher acetic acid was recorded in the $\mathrm{Cu}$ and $\mathrm{Cu}+\mathrm{Fe}$ treatments which probably contributed to the higher daily biogas yields during the late stage of fermentation. 


\subsubsection{Degradation of Lignocelluloses}

Lignocelluloses are mainly composed of cellulose, hemicellulose, lignin [49]. As shown in Table 3, lignin and cellulose contents were comparable and higher than the hemicellulose contents in all the treatments. When metal mixtures were added into the fermentation reactors, the degradation of lignocelluloses differed significantly. The addition of $\mathrm{Fe}$ and $\mathrm{Zn}$ into $\mathrm{Cu}$-containing fermenters enhanced the degradation of lignin and cellulose significantly, which resulted in a decrease in total lignocelluloses contents (One-Way ANOVA, $p<0.01$ ). In contrast, $\mathrm{Ni}$ addition did not improve the degradability of the feedstocks.

Table 3. The average contents of cellulose, hemicellulose, lignin and total lignocellulose during the anaerobic co-fermentation of corn stover and cow dung in the presence of different metal mixtures.

\begin{tabular}{ccccc}
\hline Metals & Lignin (\% TS) & Hemicellulose (\% TS) & Cellulose $(\%$ TS) & Total Lignocellulose (\% TS) \\
\hline $\mathrm{Cu}$ & $19.63 \pm 0.85$ & $13.23 \pm 0.75$ & $19.34 \pm 1.46$ & $52.21 \pm 3.06$ \\
$\mathrm{Cu}+\mathrm{Fe}$ & $16.92 \pm 0.90$ & $11.44 \pm 0.61$ & $16.46 \pm 0.83$ & $44.83 \pm 2.34^{* *}$ \\
$\mathrm{Cu}+\mathrm{Ni}$ & $19.95 \pm 1.15$ & $12.05 \pm 0.69$ & $20.21 \pm 0.74$ & $52.21 \pm 2.58$ \\
$\mathrm{Cu}+\mathrm{Zn}$ & $14.56 \pm 1.03 * *$ & $12.34 \pm 0.61$ & $14.43 \pm 1.18^{* *}$ & $41.34 \pm 2.82^{* *}$ \\
\hline
\end{tabular}

Mean \pm Standard Error; $n=10$; One-Way ANOVA; ${ }^{* *} p<0.01$; TS-total solid.

Figure 5 shows the effects of metal mixtures on lignocelluloses compositions during the fermentation process. On the 1st day of fermentation, the addition of $\mathrm{Fe}, \mathrm{Ni}$ and $\mathrm{Zn}$ into the $\mathrm{Cu}$-containing fermenter promoted the degradation of lignocelluloses, in particular cellulose and hemicellulose, resulting in higher daily biogas yields than the $\mathrm{Cu}$ treatment. Afterwards, the lignocelluloses contents of $\mathrm{Cu}+\mathrm{Ni}$ treatment were generally higher than $\mathrm{Cu}+\mathrm{Fe}$ and $\mathrm{Cu}+\mathrm{Zn}$ treatments, especially for the cellulose contents. Therefore, Ni probably did not contribute significantly to the cellulose degradation. The high biogas yields of the $\mathrm{Cu}+\mathrm{Ni}$ treatment was likely due to the degradation of hemicellulose and other non-lignocellulose components during the early stage of fermentation. A previous study on the anaerobic fermentation of Phragmites straw and cow dung found $\mathrm{Cu}$ addition enhanced the degradation of lignin and hemicellulose [8]. In the present study, the addition of $\mathrm{Zn}$ increased the degradation of cellulose. Therefore, $\mathrm{Zn}$ combining $\mathrm{Cu}$ was suggested for the further degradation of lignocellulose and higher biogas yields.

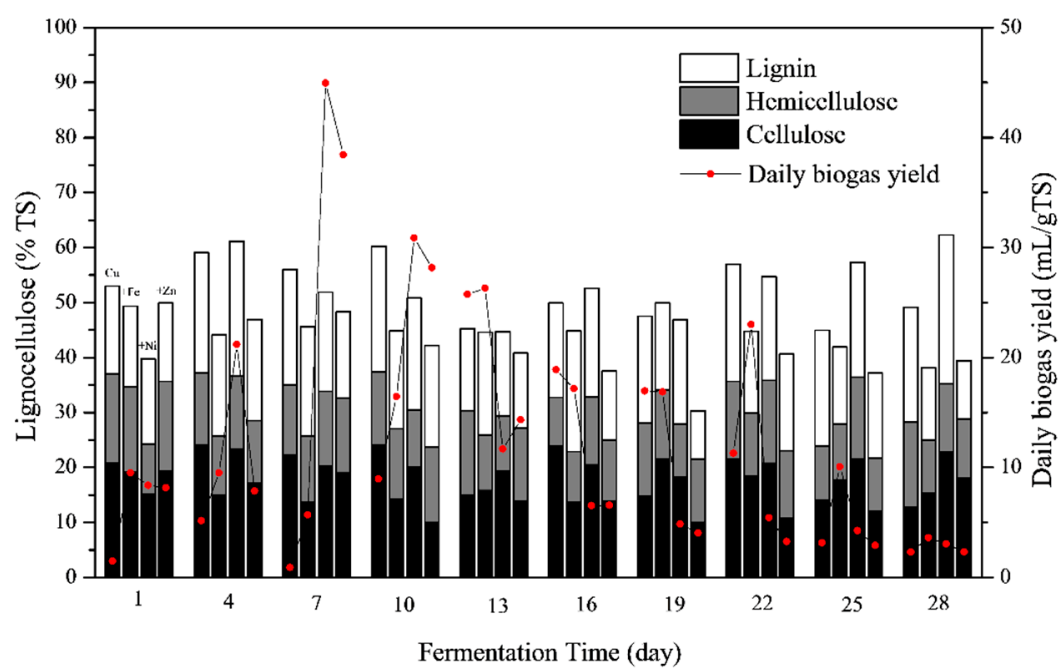

Figure 5. Lignocelluloses contents during the fermentation process. For each day, the column from left to right shows the lignocelluloses contents of $\mathrm{Cu}, \mathrm{Cu}+\mathrm{Fe}, \mathrm{Cu}+\mathrm{Ni}$ and $\mathrm{Cu}+\mathrm{Zn}$ treatments, respectively. The compositions of lignocelluloses were shown by stacked bars in the order of cellulose (black), hemicellulose (gray) and lignin (blank) from bottom. 


\subsection{Responses of Enzyme Activity}

\subsubsection{Cellulase}

Cellulase activity is often influenced by cellulose contents and COD in the liquid phase of the substrate. There was a 13-day lag in the cellulase activity of the Cu treatment (Figure 6a), which corresponded with the cellulose content and daily biogas yields (Figure 1b). The trend of cellulase activity in the $\mathrm{Cu}$ treatment was different from a previous study on the anaerobic fermentation of Phragmites straw and cow dung [8]. However, the subsequent degradation of cellulose suggests cellulase activity was probably influenced by the type of feedstocks.

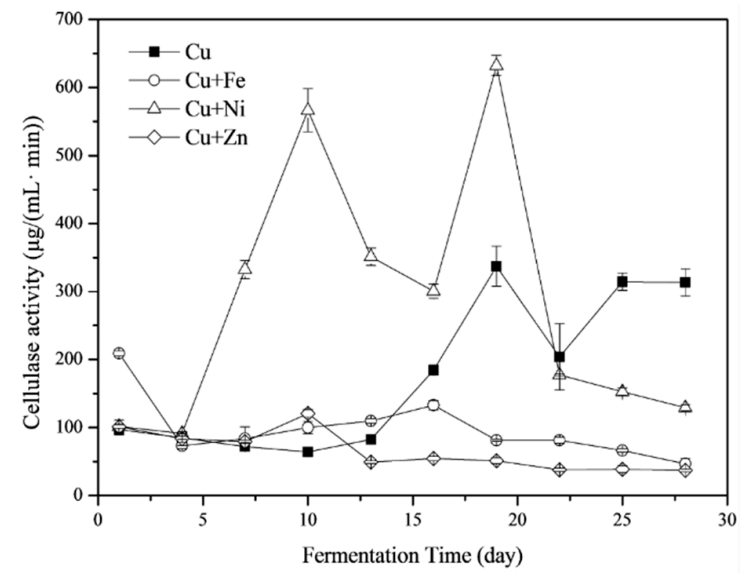

(A)

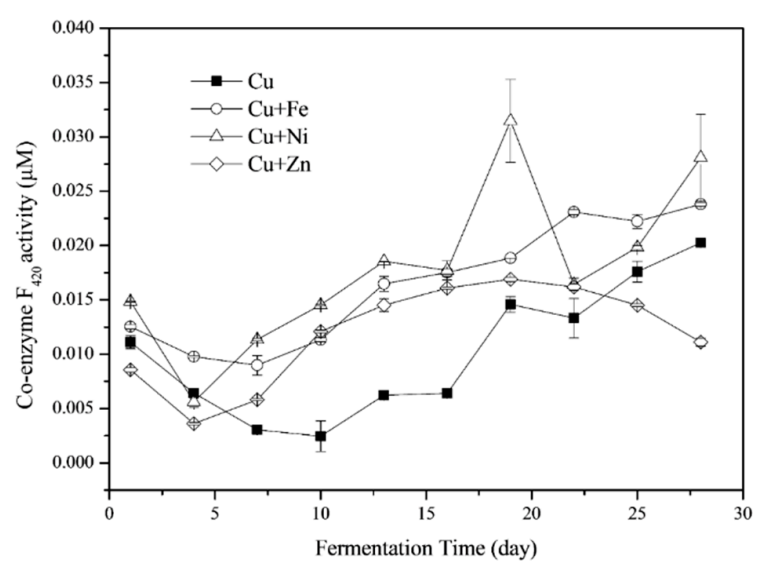

(B)

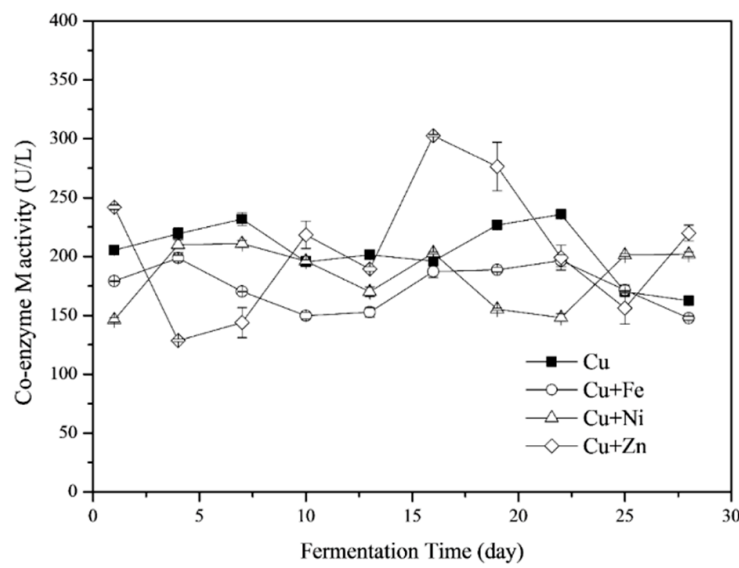

(C)

Figure 6. Responses of cellulase (A), coenzyme $\mathrm{F}_{420}(\mathbf{B})$ and coenzyme $\mathrm{M}(\mathbf{C})$ to $\mathrm{Fe}$, $\mathrm{Ni}$ and $\mathrm{Zn}$ combined with $\mathrm{Cu}$.

The average cellulase activities were $175.43 \pm 35.18,98.45 \pm 14.42,283.5 \pm 60.65$ and $65.36 \pm 9.26 \mu \mathrm{g} /(\mathrm{mL} \mathrm{min})$ for $\mathrm{Cu}, \mathrm{Cu}+\mathrm{Fe}, \mathrm{Cu}+\mathrm{Ni}$ and $\mathrm{Cu}+\mathrm{Zn}$ treatments, respectively. The addition of $\mathrm{Ni}$ induced significantly higher cellulase activities than $\mathrm{Cu}$ alone (One-Way ANOVA, $p<0.05$ ). However, high cellulase activity did not result in a corresponding significant reduction in cellulose contents probably because $\mathrm{Ni}$ addition enhanced the degradation of hemicellulose and other non-lignocellulose components, resulting in the production of cellulose in the total solid (TS) (Table 3). On the contrary, the cellulase activities in the $\mathrm{Cu}+\mathrm{Zn}$ treatment were significantly lower than in $\mathrm{Cu}$ treatment (One-Way ANOVA, $p<0.05)$ while the cellulose contents were significantly reduced. The results suggested lower cellulase activity may not be causally related to lower cellulose degradation. Hence, there is a need for 
a comprehensive study on the mechanism of cellulose degradation in the anaerobic fermentation of biowaste impacted by metals.

\subsubsection{Coenzyme $\mathrm{F}_{420}$}

The activity of coenzyme $\mathrm{F}_{420}$ is an index-a measure of methanogens activity [50,51]. Similar to the cellulase activities, the coenzyme $\mathrm{F}_{420}$ activities in the $\mathrm{Cu}$ treatment declined at the beginning of fermentation and recovered after the 13th day (Figure $6 \mathrm{~b}$ ). The same trend was found in $\mathrm{Cu}+\mathrm{Fe}$ and $\mathrm{Cu}+\mathrm{Ni}$ treatments. Differently, coenzyme $\mathrm{F}_{420}$ activities in the $\mathrm{Cu}+\mathrm{Zn}$ treatment decreased at the later stage of fermentation (after the 19th day). The average coenzyme $\mathrm{F}_{420}$ activities were $0.010 \pm 0.002,0.016 \pm 0.002,0.018 \pm 0.002$ and $0.012 \pm 0.001 \mu \mathrm{M}$ for $\mathrm{Cu}, \mathrm{Cu}+\mathrm{Fe}, \mathrm{Cu}+\mathrm{Ni}$ and $\mathrm{Cu}+\mathrm{Zn}$ treatments, respectively. Fe and $\mathrm{Ni}$ addition significantly improved the activity of coenzyme $\mathrm{F}_{420}$ (One-Way ANOVA, $p<0.05$ for $\mathrm{Cu}+\mathrm{Fe}$ treatment and $p<0.01$ for $\mathrm{Cu}+\mathrm{Ni}$ treatment).

Coenzyme $\mathrm{F}_{420}$ plays a critical function in the $\mathrm{H}_{2} / \mathrm{CO}_{2}$ pathway for $\mathrm{CH}_{4}$ production [8]. In most systems, approximately $70 \%$ of the carbon fixed in $\mathrm{CH}_{4}$ was derived from acetate. Only minor amounts, up to approximately $30 \%$, were deduced from the $\mathrm{H}_{2} / \mathrm{CO}_{2}$ pathway $[52,53]$. However, the relative contribution of $\mathrm{H}_{2} / \mathrm{CO}_{2}$ versus acetate as metabolic precursors for methanogens can be quite different in different anaerobic environments [53]. As shown in Figures $6 b$ and $1 c$, the coenzyme $F_{420}$ activities of all four treatments declined while $\mathrm{CH}_{4}$ contents increased after the experiment started. During this period, the acetate pathway likely played a main role in $\mathrm{CH}_{4}$ production. Afterwards, the increase in coenzyme $\mathrm{F}_{420}$ activities contributed to the transformation of $\mathrm{H}_{2}$ and $\mathrm{CO}_{2}$ and the rapid increase in $\mathrm{CH}_{4}$ contents.

\subsubsection{Coenzyme $M$}

Though methanogens may differ in terms of their preference for initial substrates (formate, acetate and/or $\mathrm{H}_{2} / \mathrm{CO}_{2}$ ), all of them synthesize a common compound, coenzyme $\mathrm{M}$ (2-mercaptoethane sulphonate) [54]. The limitation of the coenzyme $M$ availability to methanogens subsequently suppressed the activity of MCR in methanogens, which in turn reduced the methanogenesis rate [55]. The activities of coenzyme $M$ fluctuated during the fermentation process and the variation in the $\mathrm{Cu}+\mathrm{Zn}$ treatment was more dramatic than other treatments (Figure 6c). The average activities of coenzyme $\mathrm{M}$ were $204.39 \pm 7.85,174.16 \pm 6.05,184.24 \pm 8.35$ and $207.63 \pm 17.81 \mathrm{U} / \mathrm{L}$ for $\mathrm{Cu}, \mathrm{Cu}+\mathrm{Fe}$, $\mathrm{Cu}+\mathrm{Ni}$ and $\mathrm{Cu}+\mathrm{Zn}$ treatments, respectively. There was no significant difference between different treatments (One-Way ANOVA, $p>0.05$ ).

$\mathrm{Zn}$ took part in the functioning of enzymes involved in methanogenesis such as coenzyme $\mathrm{M}$ methyltransferase [16]. Ni in methanogens was expected to influence coenzyme $\mathrm{M}$ concentrations [56], which was however not found in the present study, possibly due to the low concentrations and availability of Ni. Furthermore, the increment of coenzyme M contents in the cells of Methanosarcina acetivorans was triggered by $\mathrm{Cd}^{2+}$ stress [57]. The responses of coenzyme $\mathrm{M}$ to metal stress needed to be studied in detail together with the metal analysis in the cells of methanogens.

\subsection{Impacts of Metal Mixtures on the Microbial Communities}

\subsubsection{Structure of Microbial Communities}

Microbial community variations annotated at the level of genus are shown in Figure 7. In the 35 most distributed microorganisms on the level of genus, there were only two archaea with others being bacteria. The metal mixtures exerted different influences on both bacterial and archaeal communities as the fermentation progressed. For the bacterial communities, Prevotella_7, Acinetobacter, Comamonas and Dysgonomonas were the dominant microorganisms of the $\mathrm{Cu}$ treatment on the 7th day. Prevotella, previously classified in the genus Bacteroides, is an obligate anaerobic gram-negative rod-shape bacterium [58]. It has a limited ability to ferment amino acid and previous studies found that it negatively correlated with a number of pathways involved in amino acid metabolism and 
carbohydrate metabolism, including short-chain fatty acid metabolism as well as pathways involving nitrogen, sulfur, and $\mathrm{CH}_{4}$ metabolism [59]. Although Acinetobacter and Comamonas require oxygen for survival, they were found in the $\mathrm{Cu}$ treatment and further research on their role in anaerobic fermentation might be necessary.

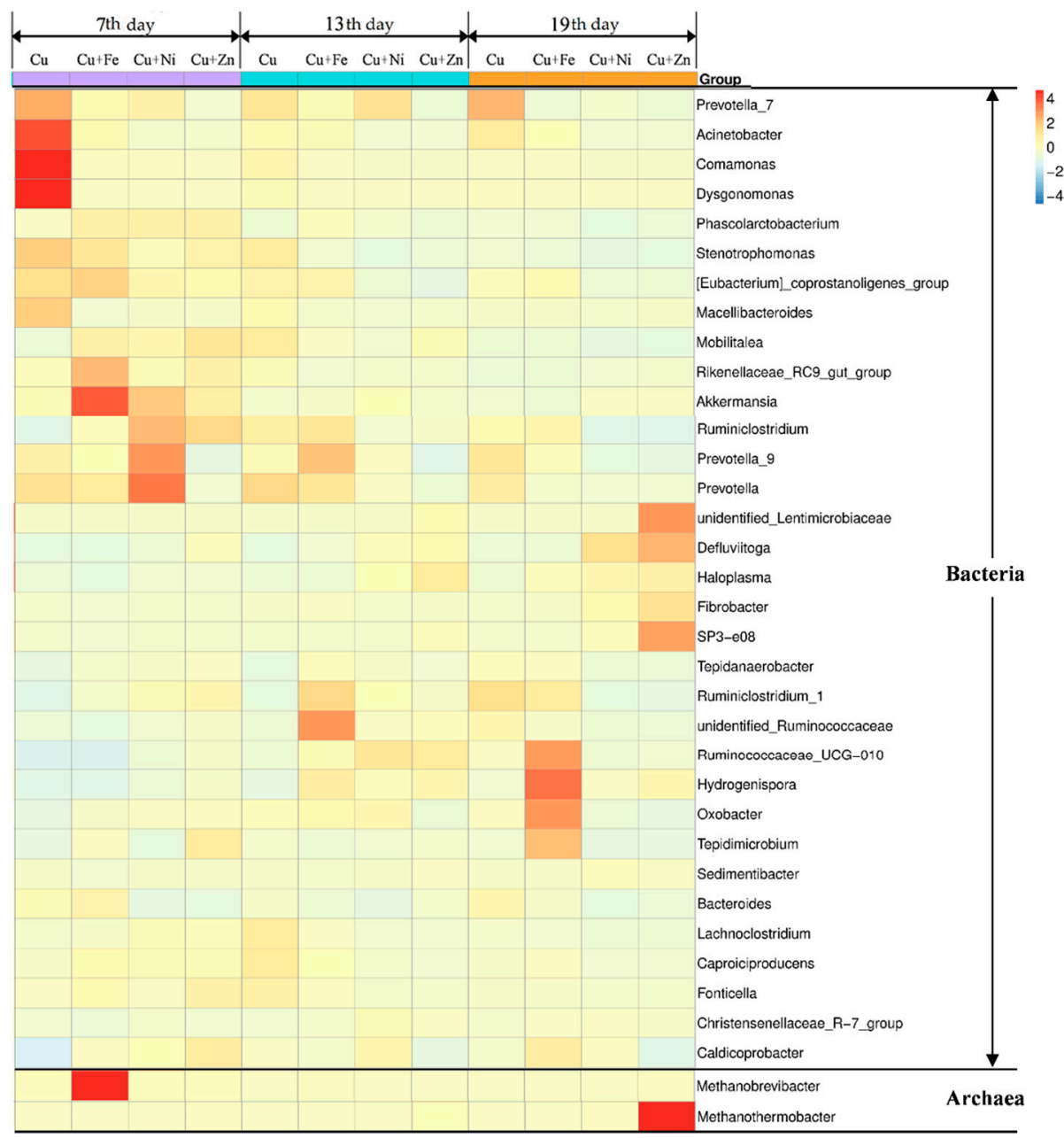

Figure 7. Microbial communities annotated on the level of genus in $\mathrm{Cu}, \mathrm{Cu}+\mathrm{Fe}, \mathrm{Cu}+\mathrm{Ni}$ and $\mathrm{Cu}+\mathrm{Zn}$ treatments on the 7th, 13th and 19th day of fermentation. Colors represent the normalized sequences number of the operational taxonomic units (OTUs) in the samples (blue: low sequences number of OTUs; red: high sequences number of OTUs).

In the $\mathrm{Cu}+$ Fe treatment, the dominant bacteria were Rikenellaceae_RC9_gut_group and Akkermansia . To date, all cultured members of the family Rikenellaceae were described as anaerobic, mesophilic, rod-shaped bacteria that usually ferment carbohydrates or proteins [60]. Therefore, the detected microbial communities in the $\mathrm{Cu}+\mathrm{Fe}$ treatment supported the carbohydrates and proteins degradation. In the $\mathrm{Cu}+\mathrm{Ni}$ treatment, the main bacteria were Ruminclostridium, Prevotella_9 and Prevotella. As previously reported, Ruminiclostridium cellulolyticum produce extracellular multi-enzymatic complexes called cellulosomes, which efficiently degrade the crystalline cellulose and the cell wall [61]. Thus, Ruminiclostridium in the $\mathrm{Cu}+\mathrm{Ni}$ treatment contributed to the decrease in cellulose on the 7th day (comparing with the cellulose contents on the 4th day in Figure 5). The $\mathrm{Cu}+\mathrm{Zn}$ treatment had a lower sequence number of the OTUs than other treatments, with the Ruminclostridium slightly higher than other bacteria.

On the 13th day, the sequence number of unidentified_Ruminococcaceae in the $\mathrm{Cu}+\mathrm{Fe}$ treatment increased while other bacteria decreased. Ruminococcaceae belonged to the Firmicutes which have been 
shown to be capable of assimilating polysaccharides such as cellulose and starch $[62,63]$. The bacteria in all other groups were detected with lower abundance.

On the 19th day, the Prevotella_7 in the $\mathrm{Cu}$ treatment recovered and were the dominant genus (Figure 7). For $\mathrm{Cu}+$ Fe treatment, the sequence number of Ruminococcaceae _UCG_010, Hydrogenispora, Oxobacter and Tepidimicrobium were enhanced. Members of the genus Tepidimicrobium are anaerobic, moderately thermophilic and neutrophilic, with the temperature range for optimum growth $25-67^{\circ} \mathrm{C}$ and the $\mathrm{pH}$ range for optimum growth 5.5-9.5 [64]. Tepidimicrobium spp. grew organotrophically on a number of proteinaceous substrates, amino acids, and carbohydrates [64] and produced acetic acid, ethanol, $\mathrm{H}_{2}$ and $\mathrm{CO}_{2}$. Oxobacter, an endospore-forming microorganism, obligately anaerobic, was able to catabolize pyruvateto into acetate and $\mathrm{CO}_{2}$ [65]. Meanwhile, the coenzyme $\mathrm{F}_{420}$ activity in the $\mathrm{Cu}+\mathrm{Fe}$ treatment was high on the 19th day (Figure 7). Therefore, the $\mathrm{H}_{2}$ and $\mathrm{CO}_{2}$ were efficiently generated and used for $\mathrm{CH}_{4}$ production at this time.

For the $\mathrm{Cu}+\mathrm{Zn}$ treatment, the sequence number of unidentified_Lentimicrobiaceae were highest followed by a SP3-e08, Defluviitoga and Fibrobacter. A new isolate L3 of Defluviitoga tunisiensis was able to degrade cellulose since genes encoding non-cellulosomal cellulases have been previously identified in the islaltes' genome [66]. Acetate, $\mathrm{H}_{2}$ and $\mathrm{CO}_{2}$ were the probable end products of the fermentation process. Fibrobacter succinogenes, a predominant cellulolytic rumen bacterium, was previously suggested to be capable of degrading cellulose via a very efficient cellulolytic system [67]. The high abundance of Defluviitoga and Fibrobacter in the $\mathrm{Cu}+\mathrm{Zn}$ treatment probably enhanced the decrease in cellulose obseved in Figure 6.

For the archaeal communities, on the 7th day, Methanobrevibacter in the $\mathrm{Cu}+\mathrm{Fe}$ treatment was dominant. All the Methanobrevibacter species are hydrogenotrophs [68] and use $\mathrm{H}_{2}$ and/or formate as substrate for their $\mathrm{CH}_{4}$ production [69]. The positive correlation between Methanobrevibacter and $\mathrm{CH}_{4}$ metabolism was previously reported [59]. Thus, Methanobrevibacter in the $\mathrm{Cu}+\mathrm{Fe}$ group contributed to the generation of $\mathrm{CH}_{4}$ from $\mathrm{H}_{2}$. On the 19th day, the sequence number of Methanothermobacter was highest in $\mathrm{Cu}+\mathrm{Zn}$ treatment. Methanothermobacter were strictly anaerobic with the fastest growth observed between 55 and $65^{\circ} \mathrm{C}$ [70]. Their energy metabolism is followed by the reduction of $\mathrm{CO}_{2}$ to $\mathrm{CH}_{4}$, with $\mathrm{H}_{2}$ as an electron donor but some cells can use formate as electron donor instead [70]. It indicated that $\mathrm{Zn}$ addition into the $\mathrm{Cu}$-containing group enhanced the growth of Methanothermobacter which promoted the transformation of $\mathrm{H}_{2} / \mathrm{CO}_{2}$ to $\mathrm{CH}_{4}$.

\subsubsection{Methanogens and Their Relationships with Fermentation Parameters}

The absolute abundance of the methanogens at different stages of fermentation are shown in Figure 8. It was found that the total abundance of methanogens in the $\mathrm{Cu}$ treatment was lowest during the whole fermentation process. Ni addition increased the total abundance of methanogens slightly. For the $\mathrm{Cu}+\mathrm{Fe}$ treatment, the total abundance of methanogens on the 7 th day were much higher than other treatments with Methanobrevibacter as the dominant genus, followed by Methanobacterium. These result agreed with a previous study that found Fe was required by enzymes from Methanobacterium [54] as well as detected Ni in Methanobrevibacter [71]. However, the Methanobrevibacter was not dominant in $\mathrm{Cu}+\mathrm{Ni}$ treatment probably due to the low concentrations and bioavailability of $\mathrm{Ni}$. For $\mathrm{Cu}+\mathrm{Zn}$ treatment, the total abundances of methanogens were higher than other treatments on the 13th and 19th day. In particular, the main methanogens in this treatment on the 19th day were identified as Methanothermobacter, which were $>700$ times higher than the $\mathrm{Cu}$ treatment. 


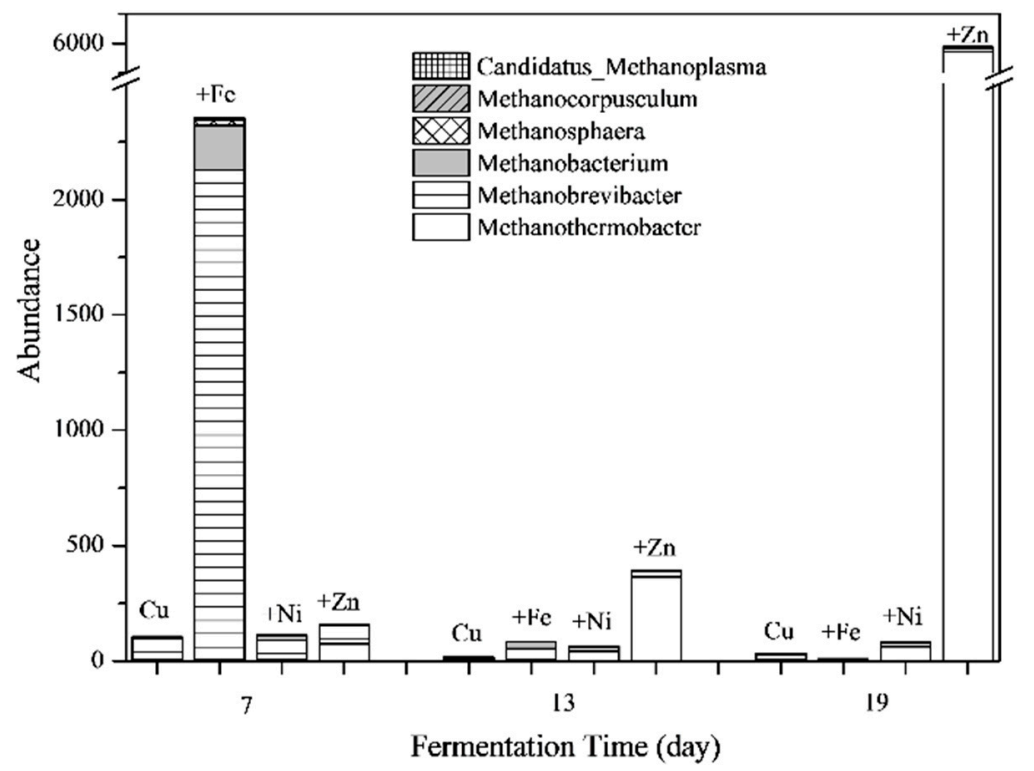

Figure 8. Responses of the absolute abundance of methanogens to $\mathrm{Fe}, \mathrm{Ni}$ and $\mathrm{Zn}$ combined with $\mathrm{Cu}$ addition.

The relationships between the methanogens and fermentation parameters were determined using Pearson correlation analysis and the results are shown in Figure 9. For $\mathrm{Cu}$ treatment, Methanobrevibacter $(p<0.05)$, Methanosphaera $(p<0.01)$ and Methanocorpusculum $(p<0.01)$ were positively correlated to the cellulose contents. However, cellulose contents were not correlated to methanogens in the compounding metal treatments. For $\mathrm{Cu}+\mathrm{Fe}$ treatment, Methanobacterium was negatively correlated to $\mathrm{CH}_{4}$ contents and $\mathrm{pH}$ values $(p<0.05)$. Methanothermobacter was positively correlated to COD $(p<0.01)$. Methanobacterium and Methanobrevibacter were positively correlated to total VFA and acetate concentrations $(p<0.05)$. Candidatus_Methanoplasma, Methanocorpusculum, and Methanosphaera were positively correlated to total VFA concentrations $(p<0.05)$. For $\mathrm{Cu}+\mathrm{Ni}$ treatment, Methanothermobacter was positively correlated to $\mathrm{pH}$ values $(p<0.05)$, which was contrary to Candidatus_Methanoplasma (negatively, $p<0.05$ ). Methanobrevibacter and Methanobacterium were found to be positively correlated to total VFA $(p<0.05)$ and the former was positively correlated to hemicellulose contents $(p<0.05)$, while the later was positively correlated to acetate concentrations $(p<0.01)$. Candidatus_Methanoplasma was positively correlated to the coenzyme M activities $(p<0.05)$ while no other detected methanogens were correlated to cellulase, coenzyme $\mathrm{F}_{420}$ or coenzyme $\mathrm{M}$ in the $\mathrm{Cu}$ or other metal mixtures treatments. There were no significant relationships between the methanogens and fermentation parameters in the $\mathrm{Cu}+\mathrm{Zn}$ treatment.

According to the abovementioned results, it was found that although the addition of metal mixtures induced the variation of methanogens during the fermentation process, this variation could not adequately explain the impacts of metals on biogas production. It seems the archaeal communities together with bacteria communities determined the degradation of feedstocks as well as the generation of $\mathrm{CH}_{4}$. 


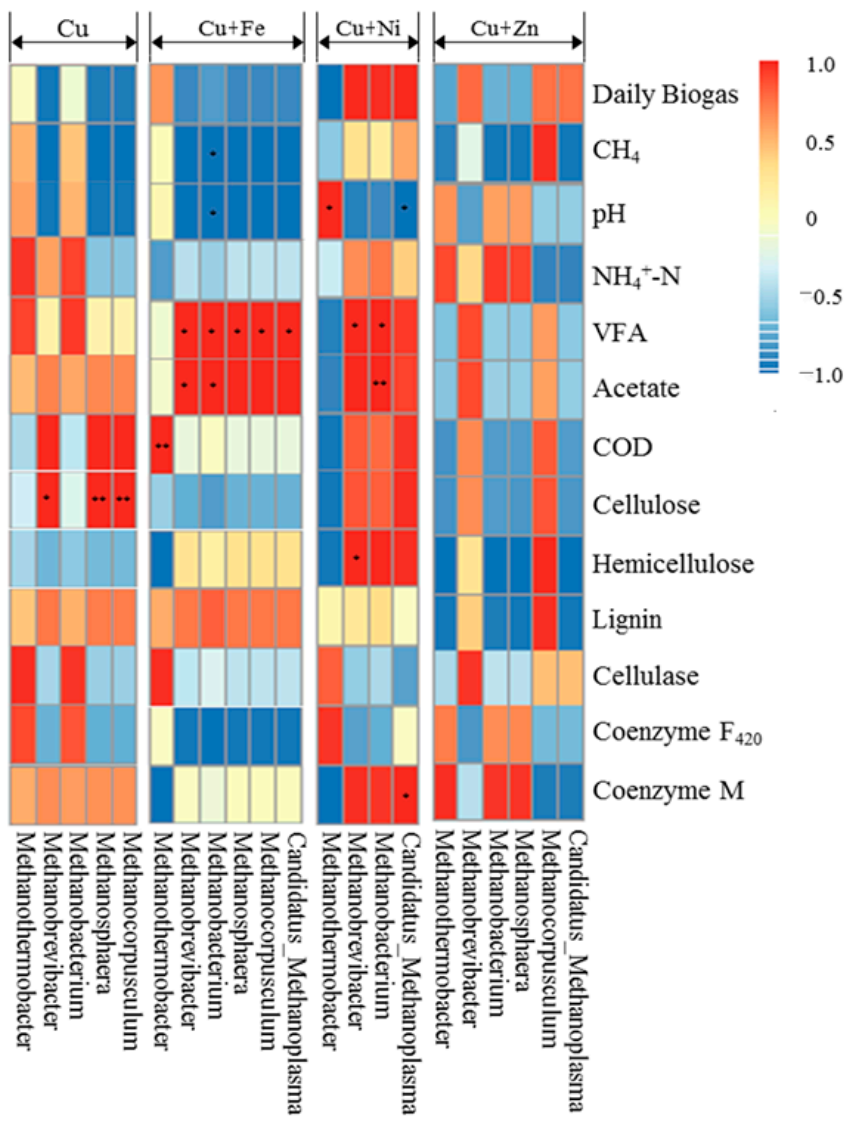

Figure 9. Pearson correlations between methanogens and fermentation parameters $\left({ }^{*}, p<0.05 ;{ }^{* *}\right.$, $p<0.01) . \mathrm{NH}_{4}{ }^{+}-\mathrm{N}$, ammonia nitrogen; COD, chemical oxygen demands; VFA, volatile fatty acids. Different colors represent the correlation coefficients from -1 (blue) to 1 (red) as shown in the right.

\section{Conclusions}

This study investigated the effects of a combination of $\mathrm{Cu}$ and $\mathrm{Fe}, \mathrm{Ni}$ and $\mathrm{Zn}$ on the anaerobic fermentation of corn stover mixed with cow dung as feedstocks. The addition of metal mixtures, particularly $\mathrm{Ni}$ and $\mathrm{Zn}$, improved the biogas yields and resulted in the one-phase decomposition process. The stimulatory mechanism of metal mixtures was demonstrated by improvements in process stability, efficiency in transformation and utilization of VFAs, and higher activities of coenzyme $\mathrm{F}_{420}$, and better degradation of lignin and cellulose. The effect of metal mixtures was strongly associated to the microbial communities rather than the methanogens themselves during the fermentation process. The addition of Fe increased the absolute abundance of Methanobrevibacter at the early stage of fermentation while the addition of $\mathrm{Zn}$ increased the absolute abundance of Methanothermobacter at the later stage of fermentation, which contributed to the generation of $\mathrm{CH}_{4}$ from $\mathrm{CO}_{2} / \mathrm{H}_{2}$. The results of this study manifested that metal contained biowastes were of large potential in producing biogas. The control and regulation of metal mixtures in the fermenter is important in improving fermentation efficiency. Future research and practice should focus on developing a mixed microbial agent for improving degradability and $\mathrm{CH}_{4}$ yields.

Author Contributions: Conceptualization, Y.T. and H.Z.; methodology, Y.T., L.Z. and H.Hao.; software, Y.T. and L.Z.; validation, all authors; formal analysis, Y.T., L.Z. and S.L.; investigation, Y.T., H.Hao., S.L., Y.C.. and M.Y.; resources, Y.T. and H.Z.; data curation, Y.T. and H.H. (He Hao); writing-original draft preparation, Y.T.; writing-review and editing, Y.T.; visualization, Y.T. and L.Z.; supervision, H.Z.; project administration, Y.T. and H.Z.; funding acquisition, H.Z. and H.H. (Hai Huang).

Funding: This research was funded by the Major Science and Technology Program for Water Pollution Control and Treatment, grant number 2017ZX07101003; and the Fundamental Research Funds for the Central Universities, grant number 2018MS051. 
Acknowledgments: We acknowledge Beijing Dairy Cattle Centre for kindly supplying cow dung for the experiments. We thank Edmond Sanganyado for polishing the language of the revised manuscript.

Conflicts of Interest: The authors declare no conflict of interest.

\section{References}

1. Rezania, S.; Ponraj, M.; Talaiekhozani, A.; Sabbagh, F.; Sairan, F. Perspectives of phytoremediation using water hyacinth for removal of heavy metals, organic and inorganic pollutants in wastewater. J. Environ. Manag. 2015, 163, 125-133. [CrossRef] [PubMed]

2. Zhang, H.; Tian, Y.; Wang, L.; Zhang, L.; Dai, L. Ecophysiological characteristics and biogas production of cadmium-contaminated crops. Bioresour. Technol. 2013, 146, 628-636. [CrossRef] [PubMed]

3. Tian, Y.; Zhang, H. Producing biogas from agricultural residues generated during phytoremediation process: Possibility, threshold, and challenges. Int. J. Green Energy 2016, 13, 1556-1563. [CrossRef]

4. Fernandes, K.D.; Cañote, S.J.B.; Ribeiro, E.M.; Thiago Filho, G.L.; Fonseca, A.L. Can we use Cd-contaminated macrophytes for biogas production? Environ. Sci. Pollut. Res. 2018, 1-11. [CrossRef] [PubMed]

5. Zhang, H.; Han, X.; Tian, Y.; Li, Y.; Yang, K.; Hao, H.; Chai, Y.; Xu, X. Process analysis of anaerobic fermentation of Phragmites australis straw and cow dung exposing to elevated chromium (VI) concentrations. J. Environ. Manag. 2018, 224, 414-424. [CrossRef] [PubMed]

6. Manyiloh, C.E.; Mamphweli, S.N.; Meyer, E.L.; Okoh, A.I.; Makaka, G.; Simon, M. Microbial anaerobic digestion (Bio-Digesters) as an approach to the decontamination of animal wastes in pollution control and the generation of renewable energy. Int. J. Environ. Res. Public Health 2013, 10, 4390-4417. [CrossRef]

7. Zhang, H.; Tian, Y.; Wang, L.; Mi, X.; Chai, Y. Effect of ferrous chloride on biogas production and enzymatic activities during anaerobic fermentation of cow dung and Phragmites straw. Biodegradation 2016, 27, 69-82. [CrossRef] [PubMed]

8. Hao, H.; Tian, Y.; Zhang, H.; Chai, Y. Copper stressed anaerobic fermentation: biogas properties, process stability, biodegradation and enzyme responses. Biodegradation 2017, 28, 369-381. [CrossRef]

9. Tian, Y.; Zhang, H.; Chai, Y.; Wang, L.; Mi, X.; Zhang, L.; Ware, M.A. Biogas properties and enzymatic analysis during anaerobic fermentation of Phragmites australis straw and cow dung: influence of nickel chloride supplement. Biodegradation 2017, 28, 15-25. [CrossRef]

10. Jain, S.K.; Gujral, G.S.; Jha, N.K.; Vasudevan, P. Production of biogas from Azolla pinnata R.Br and Lemna minor L.: Effect of heavy metal contamination. Bioresour. Technol. 1992, 41, 273-277. [CrossRef]

11. Lin, C.Y.; Chen, C.C. Effect of heavy metals on the methanogenic UASB granule. Water Res. 1999, 33, 409-416. [CrossRef]

12. Elbana, T.A.; Magdi Selim, H.; Akrami, N.; Newman, A.; Shaheen, S.M.; Rinklebe, J. Freundlich sorption parameters for cadmium, copper, nickel, lead, and zinc for different soils: Influence of kinetics. Geoderma 2018, 324, 80-88. [CrossRef]

13. Jeke, N.N.; Zvomuya, F.; Badiou, P.; Ross, L.; Cicek, N. Biomass, nutrient, and trace element accumulation and partitioning in cattail (L.) during wetland phytoremediation of municipal biosolids. J. Environ. Qual. 2015, 44, 1541-1549. [CrossRef] [PubMed]

14. Salem, Z.B.; Laffray, X.; Ashoour, A.; Ayadi, H.; Aleya, L. Metal accumulation and distribution in the organs of Reeds and Cattails in a constructed treatment wetland (Etueffont, France). Ecol. Eng. 2014, 64, 1-17. [CrossRef]

15. Chan, P.C.; de Toledo, R.A.; Iu, H.I.; Shim, H. Effect of zinc supplementation on biogas production and short/long chain fatty acids accumulation during anaerobic co-digestion of food waste and domestic wastewater. Waste Biomass Valor. 2018, 1-11. [CrossRef]

16. Scherer, P.; Lippert, H.; Wolff, G. Composition of the major elements and trace elements of 10 methanogenic bacteria determined by inductively coupled plasma emission spectrometry. Biol. Trace Elem. Res. 1983, 5, 149-163. [CrossRef]

17. Zhang, Y.; Zhang, Z.; Suzuki, K.; Maekawa, T. Uptake and mass balance of trace metals for methane producing bacteria. Biomass Bioenergy 2003, 25, 427-433. [CrossRef]

18. Lenártová, V.; Holovská, K.; Javorský, P. The influence of mercury on the antioxidant enzyme activity of rumen bacteria Streptococcus bovis and Selenomonas ruminantium. Fems Microbiol. Ecol. 1998, 27, 319-325. [CrossRef] 
19. Yue, Z.B.; Yu, H.Q.; Wang, Z.L. Anaerobic digestion of cattail with rumen culture in the presence of heavy metals. Bioresour. Technol. 2007, 98, 781-786. [CrossRef]

20. Jackson-Moss, C.A.; Duncan, J.R. The effect of iron on anaerobic digestion. Biotechnol. Lett. 1990, 12, $149-154$. [CrossRef]

21. Glass, J.B.; Orphan, V.J. Trace metal requirements for microbial enzymes involved in the production and consumption of methane and nitrous oxide. Front. Microbiol 2012, 3, 1-20. [CrossRef] [PubMed]

22. Mudhoo, A.; Kumar, S. Effects of heavy metals as stress factors on anaerobic digestion processes and biogas production from biomass. Int. J. Environ. Sci. Technol. 2013, 10, 1383-1398. [CrossRef]

23. Amen, T.W.M.; Eljamal, O.; Khalil, A.M.E.; Sugihara, Y.; Matsunaga, N. Methane yield enhancement by the addition of new novel of iron and copper-iron bimetallic nanoparticles. Chem. Eng. Process. Intensif. 2018, 130, 253-261. [CrossRef]

24. Ragsdale, S.W. Nickel-based enzyme systems. J. Biol. Chem. 2009, 284, 18571-18575. [CrossRef] [PubMed]

25. Warkentin, E.; Thauer, R.K.; Ermler, U. Structure and function of enzymes involved in the methanogenic pathway utilizing carbon dioxide and molecular hydrogen. J. Biosci. Bioeng. 2002, 93, 519-530.

26. Zandvoort, B.M.H.; Van Hullebusch, E.D.; Fermoso, F.G.; Lens, P.N.L. Trace metals in anaerobic granular sludge reactors: Bioavailability and dosing strategies. Eng. Life Sci. 2006, 6, 293-301. [CrossRef]

27. Thauer, R.K.; Kaster, A.; Goenrich, M.; Schick, M.; Hiromoto, T.; Shima, S. Hydrogenases from methanogenic archaea, mickel, a novel cofactor, and $\mathrm{H}_{2}$ storage. Annu. Rev. Biochem. 2010, 79, 507-536. [CrossRef]

28. Sawers, R.G. Nickel in bacteria and archaea. In Encyclopedia of Metalloproteins; Kretsinger, R.H., Uversky, V.N., Permyakov, E.A., Eds.; Springer: New York, NY, USA, 2013; pp. 1490-1496.

29. Chen, Y.; Cheng, J.J.; Creamer, K.S. Inhibition of anaerobic digestion process: A review. Bioresour. Technol. 2008, 99, 4044-4064. [CrossRef]

30. Cao, Z.; Wang, S.; Wang, T.; Chang, Z.; Shen, Z.; Chen, Y. Using contaminated plants involved in phytoremediation for anaerobic digestion. Int. J. Phytoremed. 2015, 17, 201-207. [CrossRef]

31. Clark, P.B.; Hillman, P.F. Enhancement of anaerobic digestion using duckweed (Lemna minor) enriched with iron. Water Environ. J. 1996, 10, 92-95. [CrossRef]

32. Pobeheim, H.; Munk, B.; Johansson, J.; Guebitz, G.M. Influence of trace elements on methane formation from a synthetic model substrate for maize silage. Bioresour. Technol. 2010, 101, 836-839. [CrossRef] [PubMed]

33. Pobeheim, H.; Munk, B.; Lindorfer, H.; Guebitz, G.M. Impact of nickel and cobalt on biogas production and process stability during semi-continuous anaerobic fermentation of a model substrate for maize silage. Water Res. 2011, 45, 781-787. [CrossRef] [PubMed]

34. Nkemka, V.N.; Murto, M. Evaluation of biogas production from seaweed in batch tests and in UASB reactors combined with the removal of heavy metals. J. Environ. Manag. 2010, 91, 1573-1579. [CrossRef] [PubMed]

35. Willscher, S.; Mirgorodsky, D.; Jablonski, L.; Ollivier, D.; Merten, D.; Büchel, G.; Wittig, J.; Werner, P.H. Field scale phytoremediation experiments on a heavy metal and uranium contaminated site, and further utilization of the plant residues. Hydrometallurgy 2013, 131-132, 46-53. [CrossRef]

36. Verma, V.K.; Singh, Y.P.; Rai, J.P.N. Biogas production from plant biomass used for phytoremediation of industrial wastes. Bioresour. Technol. 2007, 98, 1664-1669. [CrossRef] [PubMed]

37. Lao, J.; Chen, X.; Qi, M.; Ji, B. Soil Agrochemical Analysis Manual; Lao, J., Ed.; Agriculture Press: Beijing, China, 1988.

38. Wei, Y.; Van Houten, R.T.; Borger, A.R.; Eikelboom, D.H.; Fan, Y. Minimization of excess sludge production for biological wastewater treatment. Water Res. 2003, 37, 4453-4467. [CrossRef]

39. Su, Y. Biogas Fermentation Detection Technology; Metallurgical Industry Press: Beijing, China, 2011.

40. Allen, G.C.; Flores-Vergara, M.A.; Krasynanski, S.; Kumar, S.; Thompson, W.F. A modified protocol for rapid DNA isolation from plant tissues using cetyltrimethylammonium bromide. Nat. Protoc. 2006, 1, 2320-2325. [CrossRef]

41. Zhang, X.; Tian, X.; Ma, L.; Feng, B.; Liu, Q.; Yuan, L.; Fan, C.; Huang, H.; Huang, H.; Yang, Q. Biodiversity of the symbiotic bacteria associated with toxic marine dinoflagellate Alexandrium tamarense. J. Biosci. Med. 2015, 3, 23-28. [CrossRef]

42. Bitton, G. Wastewater Microbiology, 3rd ed.; John Wiley \& Sons, Inc.: Hoboken, NJ, USA, 2005.

43. Rajagopal, R.; Massé, D.I.; Singh, G. A critical review on inhibition of anaerobic digestion process by excess ammonia. Bioresour. Technol. 2013, 143, 632-641. [CrossRef] 
44. Liu, T.; Sung, S. Ammonia inhibition on thermophilic aceticlastic methanogens. Water Sci. Technol. 2002, 45, 113-120. [CrossRef]

45. Math-Alvarez, J.; Mtz.-Viturtia, A.; Llabrés-Luengo, P.; Cecchi, F. Kinetic and performance study of a batch two-phase anaerobic digestion of fruit and vegetable wastes. Biomass Bioenergy 1993, 5, 481-488. [CrossRef]

46. Tian, H.; Karachalios, P.; Angelidaki, I.; Fotidis, I.A. A proposed mechanism for the ammonia-LCFA synergetic co-inhibition effect on anaerobic digestion process. Chem. Eng. J. 2018, 349, 574-580. [CrossRef]

47. Tian, Y.; Yang, K.; Li, S.; Zhang, H.; Han, X.; Hao, H.; Chai, Y.; Xu, X. How does copper stress influence the relationships among the anaerobic co-fermentation parameters? J. Renew. Sustain. Energy 2018, 10, 053107. [CrossRef]

48. Tabatabaei, M.; Sulaiman, A.; Nikbakht, A.M. Influential parameters on biomethane generation in anaerobic wastewater treatment plants. In Alternative Fuel; Manzanera, M., Ed.; InTech: London, UK, 2011; pp. 227-262. ISBN 978-953-30-372-9.

49. Taherzadeh, M.J.; Karimi, K. Pretreatment of lignocellulosic wastes to improve ethanol and biogas production: A review. Int. J. Mol. Sci. 2008, 9, 1621-1651. [CrossRef] [PubMed]

50. Xi, Y.; Chang, Z.; Ye, X.; Xu, R.; Du, J.; Chen, G. Methane production from wheat straw with anaerobic sludge by heme supplementation. Bioresour. Technol. 2014, 172, 91-96. [CrossRef]

51. Miao, H.; Lu, M.; Zhao, M.; Huang, Z.; Ren, H.; Yan, Q.; Ruan, W. Enhancement of Taihu blue algae anaerobic digestion efficiency by natural storage. Bioresour. Technol. 2013, 149, 359-366. [CrossRef] [PubMed]

52. Harper, S.R.; Pohland, F.G. Recent developments in hydrogen management during anaerobic biological wastewater treatment. Biotechnol. Bioeng. 1986, 28, 585-602. [CrossRef]

53. Nettmann, E.; Bergmann, I.; Pramschu, S.; Mundt, K.; Plogsties, V.; Herrmann, C.; Klocke, M. Polyphasic analyses of methanogenic archaeal communities in agricultural biogas plants. Appl. Environ. Microbiol. 2010, 76, 2540-2548. [CrossRef]

54. Tahuer, R.K. Biochemistry of methanogenesis: A tribute to Marjory Stephenson. Microbiology 1998, 144, 2377-2406. [CrossRef]

55. Omar, B.; Abou-shanab, R.; El-gammal, M.; Fotidis, I.A.; Kougias, P.G.; Zhang, Y.; Angelidaki, I. Simultaneous biogas upgrading and biochemicals production using anaerobic bacterial mixed cultures. Water Res. 2018, 142, 86-95. [CrossRef]

56. Pramanik, P.; Kim, P.J. Effect of limited nickel availability on methane emission from EDTA treated soils: Coenzyme $\mathrm{M}$ an alternative biomarker for methanogens. Chemosphere 2013, 90, 873-876. [CrossRef] [PubMed]

57. Lira-Silva, E.; Santiago-Martínez, M.G.; García-Contreras, R.; Zepeda-Rodríguez, A.; Marín-Hernández, A.; Moreno-Sánchez, R.; Jasso-Chávez, R. $\mathrm{Cd}^{2+}$ resistance mechanisms in Methanosarcina acetivorans involve the increase in the coenzyme $\mathrm{M}$ content and induction of biofilm synthesis. Environ. Microbiol. Rep. 2013, 5, 799-808. [CrossRef] [PubMed]

58. Ruan, Y.; Shen, L.; Zou, Y.; Qi, Z.; Yin, J.; Jiang, J.; Guo, L.; He, L.; Chen, Z.; Tang, Z.; et al. Comparative genome analysis of Prevotella intermedia strain isolated from infected root canal reveals features related to pathogenicity and adaptation. BMC Genom. 2015, 16, 1-21. [CrossRef] [PubMed]

59. Petersen, L.M.; Bautista, E.J.; Nguyen, H.; Hanson, B.M.; Chen, L.; Lek, S.H.; Sodergren, E.; Weinstock, G.M. Community characteristics of the gut microbiomes of competitive cyclists. Microbiome 2017, 5, 1-13. [CrossRef] [PubMed]

60. Su, X.-L.; Shi, X.-S.; Guo, R.-B.; Qiu, Y.-L.; Tian, Q.; Yuan, X.-Z.; Zhang, J. Acetobacteroides hydrogenigenes gen. nov., sp. nov., an anaerobic hydrogen-producing bacterium in the family Rikenellaceae isolated from a reed swamp. Int. J. Syst. Evol. Microbiol. 2014, 64, 2986-2991. [CrossRef] [PubMed]

61. Fosses, A.; Maté, M.; Franche, N.; Liu, N.; Denis, Y.; Borne, R.; De Philip, P.; Fierobe, H.P.; Perret, S. A seven-gene cluster in Ruminiclostridium cellulolyticum is essential for signalization, uptake and catabolism of the degradation products of cellulose hydrolysis. Biotechnol. Biofuels 2017, 10, 1-14. [CrossRef]

62. Liu, T.; Ahn, H.; Sun, W.; McGuinness, L.R.; Kerkhof, L.J.; Häggblom, M.M. Identification of a Ruminococcaceae species as the Methyl tert-Butyl Ether (MTBE) degrading bacterium in a Methanogenic consortium. Environ. Sci. Technol. 2016, 50, 1455-1464. [CrossRef]

63. Weiss, G.A.; Hennet, T. The role of milk sialyllactose in Sialyllactose in Intestinal Bacterial Colonization. Adv. Nutr. 2012, 3, 483-488. [CrossRef]

64. Slobodkin, A. Tepidimicrobium. In Bergey's Manual of Systematics of Archaea and Bacteria; Whitman, W.B., Ed.; Wiley: Hoboken, NJ, USA, 2017; pp. 1-6. 
65. Xie, J.; Fan, J.; Wang, Z.; He, T. The stress concentration effect around the hole in flat plate. Adv. Mater. Res. 2012, 538-541, 1573-1578. [CrossRef]

66. Cibis, K.G.; Wibberg, D.; Maus, I.; Schlüter, A.; Pühler, A.; Winkler, A.; König, H.; Stolze, Y. Complete genome sequence of the strain Defluviitoga tunisiensis L3, isolated from a thermophilic, production-scale biogas plant. J. Biotechnol. 2015, 203, 17-18.

67. Matulova, M.; Delort, A.M.; Nouaille, R.; Gaudet, G.; Forano, E. Concurrent maltodextrin and cellodextrin synthesis by Fibrobacter succinogenes $\mathrm{S} 85$ as identified by 2D NMR spectroscopy. Eur. J. Biochem. 2001, 268, 3907-3915. [CrossRef] [PubMed]

68. Leahy, S.C.; Kelly, W.J.; Ronimus, R.S.; Wedlock, N.; Altermann, E.; Attwood, G.T. Genome sequencing of rumen bacteria and archaea and its application to methane mitigation strategies. Animal 2013, 7, 235-243. [CrossRef] [PubMed]

69. Schnürer, A.; Müller, B.; Dicksved, J.; Gonda, H.; Danielsson, R.; Bertilsson, J.; Sun, L. Methane production in dairy cows correlates with rumen methanogenic and bacterial community structure. Front. Microbiol. 2017, 8, 1-15.

70. Pfister, P.; Nolling, J.; Wasserfallen, A.; Conway de Macario, E.; Reeve, J. Phylogenetic analysis of 18 thermophilic Methanobacterium isolates supports the proposals to create a new genus, Methanothermobacter gen. nov., and to reclassify several isolates in three species, Methanothermobacter thermautotrophicus comb. nov., Methano. Int. J. Syst. Evol. Microbiol. 2011, 50, 43-53.

71. Hammel, K.E.; Cornwell, K.L.; Diekert, G.B.; Thauer, R.K. Evidence for a nickel-containing carbon monoxide dehydrogenase in Methanobrevibacter arboriphilicus. J. Bacteriol. 1984, 157, 975-978.

(C) 2019 by the authors. Licensee MDPI, Basel, Switzerland. This article is an open access article distributed under the terms and conditions of the Creative Commons Attribution (CC BY) license (http://creativecommons.org/licenses/by/4.0/). 